\title{
Structure and production of the benthic macroinvertebrate community in a shallow lagoon in the Bay of Cádiz
}

\author{
A. M. Arias, P. Drake \\ Instituto de Ciencias Marinas de Andalucía (C.S.I.C.), E-11510 Puerto Real, Cádiz, Spain
}

\begin{abstract}
The composition and distribution of the benthic macroinvertebrate community in a lagoon fish-pond system in the Bay of Cádiz, Spain, were studied by taking monthly samples at 4 sites during 1991. A total of 29 macroinvertebrate species, representing 16 orders, were identified. Gastropods, amphipods and chironomid larvae dominated the macrofauna in term of numbers of individuals, while in biomass terms gastropods, bivalves and polychaetes were dominant. The diversity $\left(H^{\prime}\right)$ and evenness $\left(J^{\prime}\right)$ indices of this community were low, ranging from 0.58 to 1.85 and 0.30 to 0.75 respectively (natural log base). Monthly total invertebrate density showed considerable seasonal variation, with a main peak in winter. Taking the most abundant species only, the densities of Hydrobia minoricensis, $H$. ventrosa, Microdeutopus gryllotalpa and Chironomus salinarius were positively related, and the density of Nereis diversicolor negatively related, to the biomass of benthic macroalgae (Ulva lactuca and Cladophora sp.). The density of $C$. salinarius was also positively related to the silt content in the sediment. Mean annual production varied between $13.3 \mathrm{~g} \mathrm{~m}^{-2} \mathrm{yr}^{-1}$ ash-free dry weight $\left(50.7 \mathrm{~g} \mathrm{~m}^{-2} \mathrm{yr}^{-1}\right.$ dry weight) and $27.3 \mathrm{~g} \mathrm{~m}^{-2} \mathrm{yr}^{-1}$ AFDW (122.0 $\left.\mathrm{g} \mathrm{m}^{-2} \mathrm{yr}^{-1} \mathrm{DW}\right)$ depending on the sampling site, yielding production/biomass $(P / \bar{B})$ ratios between 1.08 and $1.37 \mathrm{yr}^{-1}$. The annual production estimate for the whole system was $19.5 \mathrm{~g} \mathrm{~m}^{-2} \mathrm{yr}^{-1}$ AFDW (66.6 $\left.\mathrm{g} \mathrm{m}^{-2} \mathrm{yr}^{-1} \mathrm{DW}\right)$.
\end{abstract}

KEY WORDS: Coastal lagoon - Macrobenthic community - Diversity - Secondary production - Bay of Cádiz

\section{INTRODUCTION}

The saltmarsh zone situated in the east and south of the Bay of Cádiz, Spain, is crossed by a complex system of tidal channels and creeks that supply seawater to the saltmarsh fish-pond systems situated along their courses. Most of the saltmarsh ponds remain continuously inundated during the major part of the year, and constitute a semi-natural lagoon ecosystem exploited for extensive and semi-intensive fish culture. A similar situation has been recorded in other shallow lagoons in Europe (Amanieu 1973, Labourg 1976, Ravagnan 1978, Clement 1986, Gamito 1989).

In these shallow coastal environments characterized by a marked daily and seasonal variation of the physicochemical parameters of the water (Amanieu 1967, Fiala 1972, Labourg 1976, 1979, Chassany-de Casabianca 1980, Quignard 1984, Arias \& Drake 1987, Sacchi et al.
1988), only a small number of highly adaptable macroinvertebrate species can survive and grow. In the Bay of Cádiz this macroinvertebrate community is subject to intensive predation from fish and shorebirds (Arias 1980, Drake et al. 1984, Arias \& Drake 1985, PérezHurtado 1992), and provides the main source of food for non-intensively reared fish. Thus the study of macroinvertebrate population dynamics and natural production rates is necessary for informed decisions about the conservation and management of this lagoon system. To date, the only information available about this macroinvertebrate community consists of a preliminary inventory of the saltmarsh fish-pond fauna (Arias \& Rodriguez 1977) and a study of variations in the fauna in relation to cycles of water stagnation and renewal (Arias \& Drake 1987).

The aims of the present study were to describe community composition, distribution and abundance of 
benthic macroinvertebrate fauna of a lagoon fish-pond system in the Bay of Cádiz, and to assess natural production.

\section{MATERIAL AND METHODS}

Study area. This study was carried out in the 12.5 ha main water body (a shallow pan used for extensive fish polyculture) and in a 0.4 ha pond (used for semi-intensive culture of the seabream Sparus aurata) of the San Francisco de Asís lagoon system. This is a shallow marine enclosed environment, situated in the saltmarsh zone of the Bay of Cádiz $\left(36^{\circ} 23^{\prime}\right.$ to $36^{\circ} 37^{\prime} N, 6^{\circ} 8^{\prime}$ to $6^{\circ}$ $15^{\prime}$ W) (Fig. 1). This man-made ecosystem, in the past a saltpan system, is now exploited for marine aquaculture. Normally, from February to April, the gates of the main water body remain open in order to permit the passive entrance of fish larvae due to tidal water movements (Arias \& Drake 1990), and there is a free ex-

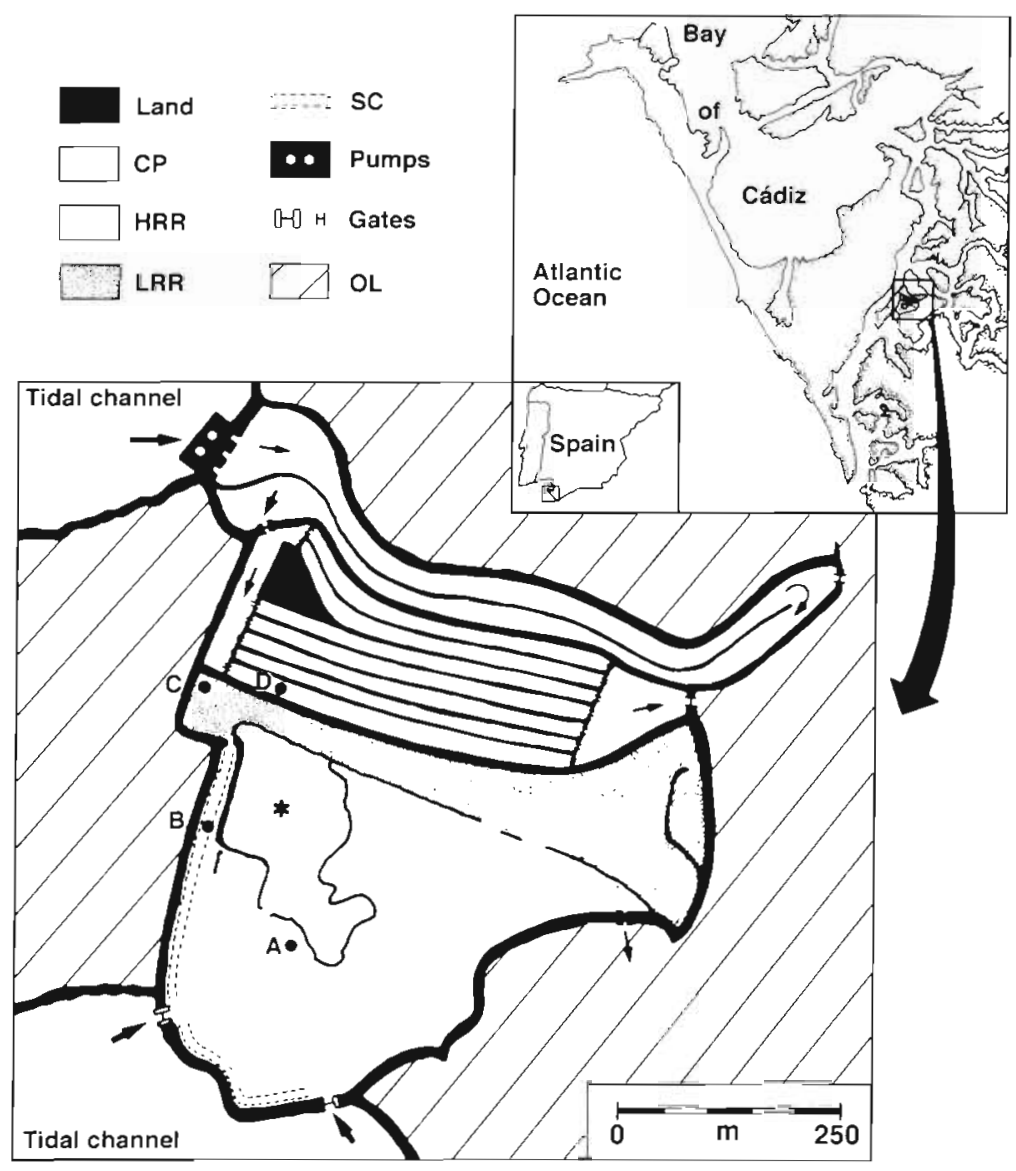

Fig. 1. San Francisco de Asís lagoon system and its location in the Bay of Cadiz, Spain. A, B, C and D: sampling sites; CP: seabream culture ponds; HRR and LRR: main water body zones with high and low renewal rates respectively; $\mathrm{SC}$ : submerged channel ${ }_{i} \mathrm{OL}$ : other lagoon systems; $*$ : fish nursery not included in this study; arrows: water circulation change of sea water with the adjacent tidal channel. During the other 9 mo (May to January), the main water body remains flooded and only at high spring tides is exchange possible, with a mean renewal rate of about $25 \%$ of the volume of enclosed water (Arias \& Drake 1987). The position of the gates and walls on the main water body determines 2 main areas on the basis of their renewal rates: (1) the area closer to gates with higher renewal rates, and (2) the area further away from gates with lower rates of water renewal (Fig. 1). In the $S$. aurata culture pond, thorough exchange of water (about $150 \% \mathrm{~d}^{-1}$ ) is made possible by continuous pumping of sea water from the tidal channel.

Three sampling sites (A, B and C) were selected in the main water body (Fig. 1). Sites $A$ and $B$ were situated in the zone with higher renewal rates. Site $A$ was located in a shallow pan with a mean water depth of 30 to $40 \mathrm{~cm}$, while Site B was positioned in a submerged channel of 60 to $70 \mathrm{~cm}$ water depth. Site $C$ was located in the zone with lower renewal rates in a shallower area ( 25 to $35 \mathrm{~cm}$ water depth) further away from the gates. When the gates remained open (February to April) Site B was always submerged, while Sites A and $\mathrm{C}$ were only flooded on some high tides. A fourth sampling station (Site D) was located in the seabream Sparus aurata culture pond.

Substratum characterization. Characteristics of the surface sediment at the 4 sampling sites were determined. Three $10 \mathrm{~cm}$ deep cores $(4.5 \mathrm{~cm} \varnothing)$ were collected, pooled, and the coarse fraction separated from the clay and silt fractions by a wet sieving process. Percentages of silt and clay were estimated by the hydrometer method (Gee \& Bauder 1986).

An index of sediment porosity was obtained by the weight loss $(\%)$ of wet sediment cores after $48 \mathrm{~h}$ at $80^{\circ} \mathrm{C}$, and of organic matter content by loss on ignition after $8 \mathrm{~h}$ at $450^{\circ} \mathrm{C}$ (Craft et al, 1991).

Faunal sampling. Invertebrates were sampled monthly from January to December 1991 at Sites A and C, and from April to December at Site B. Site D was only sampled from January to April because the pond was then emptied. Sampling was by means of an Ekman-Birge grab of $15 \times 15 \mathrm{~cm}$ (area $0.0225 \mathrm{~m}^{2}$ ) and a penetration depth of $-13 \mathrm{~cm}$ in the centre of the grab $(-10 \mathrm{~cm}$ at edges). A total of 5 (3 at Site B) randomly positioned replicates were removed from the substratum at each sampling site and kept individually 
in plastic bottles, preserved in $5 \%$ formalin. Later, each replicate was sieved through a nest of 8 sieves $(6$, $5,4,3,2,1,0.5$ and $0.3 \mathrm{~mm}$ mesh) stacked in order of decreasing mesh size. The animals retained by each of the 8 sieves were sorted into the different species under a binocular microscope and counted. From the $0.3 \mathrm{~mm}$ mesh sieve only young individuals belonging to macroinvertebrate species were considered. For elongate organisms, such as chironomid larvae, body length was measured, and for polychaete worms (which were often broken during the sieving process) body width was estimated.

Macroalgae present in each replicate were separated and washed, and their dry weight estimated $\left(80^{\circ} \mathrm{C}\right.$ for $\left.48 \mathrm{~h}\right)$. On each sampling date, water temperature and salinity were recorded.

Estimation of faunal biomass. The faunal biomass was estimated using the methods of Edgar (1990a), rather than by direct measurement because macrofaunal individuals were preserved, and because polychaetes were often broken during the sampling and sieving processes. Additional samples of macrofauna were collected during the year and fresh animals were used to estimated mean dry weight (DW, $80^{\circ} \mathrm{C}$ for $48 \mathrm{~h}$ ) and the mean ash free dry weigth (AFDW), calculated as the difference between DW and ashed $\left(500^{\circ} \mathrm{C}\right.$ for $2 \mathrm{~h}$ ) weight, for animals retained by each sieve. These values were then used to calculate the regression equations (Table 1) that relate individual mean faunal DW and AFDW with the mesh size $S$.

Because the animals retained by each sieve range in dimensions from that mesh size to the next up, $\mathrm{S}$ was expressed as the geometric mean of both sizes. Then the biomass of samples was estimated using the equation

$$
\sum_{j=1}^{k} B_{j}=\sum_{i=1}^{7} n_{i} \bar{b}_{j}
$$

where $B$, is the estimated total biomass of taxonomic group $j, k$ is the number of taxonomic groups, $n_{1}$ is the abundance of animals of the taxonomic group $j$ retained by sieve $i_{\text {, and }} \vec{b}_{j}$ is the estimated mean weight calculated from the corresponding regression equation. Animals retained in the largest $(6 \mathrm{~mm})$ sieve were mainly specimens of Cerastoderma glaucum, and the regression equations relating body length to DW and AFDW (Table 1) were used to estimate their biomass.

For elongate animals, fresh specimens were used to determine individual (or mean) DW and AFDW in relation to body length (or width) rather than sieve size,

Table 1. Equations relating the mean dry weight (DW, mg) and ash-free dry weight (AFDW, mg) to sieve mesh size ( $\mathrm{S}, \mathrm{mm}$ ), body length $(\mathrm{L}, \mathrm{mm})$ or body width $(\mathrm{W}, \mathrm{mm})$, of some invertebrate taxa. $r$ : correlation coefficient; $\mathrm{N}$ : total number of individuals used; $\mathrm{n}$ : number of values (size-groups) included in regression, left blank where sizes not grouped and $\mathrm{n}=\mathrm{N}$

\begin{tabular}{|c|c|c|c|c|}
\hline Taxon & Regression equation & $\mathrm{r}$ & $\mathrm{n}$ & $N$ \\
\hline Bivalvia & $\begin{array}{l}\mathrm{DW}=0.659 \mathrm{~S}^{2226} \\
\mathrm{AFDW}=0.108 \mathrm{~S}^{2.227}\end{array}$ & $\begin{array}{l}0.99 \\
0.99\end{array}$ & $\begin{array}{l}10 \\
10\end{array}$ & $\begin{array}{l}201 \\
201\end{array}$ \\
\hline Hydrobia sp. & $\begin{array}{l}\mathrm{DW}=0.862 \mathrm{~S}^{2750} \\
\mathrm{AFDW}=0.157 \mathrm{~S}^{2.732}\end{array}$ & $\begin{array}{l}0.96 \\
0.97\end{array}$ & $\begin{array}{l}11 \\
11\end{array}$ & $\begin{array}{l}1093 \\
1093\end{array}$ \\
\hline Sacoglossa & $\begin{array}{l}\mathrm{DW}=0.437 \mathrm{~S}^{1.559} \\
\mathrm{AFDW}=0.364 \mathrm{~S}^{1.563}\end{array}$ & $\begin{array}{l}0.99 \\
0.99\end{array}$ & $\begin{array}{l}3 \\
3\end{array}$ & $\begin{array}{l}54 \\
54\end{array}$ \\
\hline Mysidacea & $\begin{array}{l}D W=0.273 \mathrm{~S}^{1831} \\
\mathrm{AFDW}=0.248 \mathrm{~S}^{1.852}\end{array}$ & $\begin{array}{l}0.98 \\
0.98\end{array}$ & $\begin{array}{l}4 \\
4\end{array}$ & $\begin{array}{l}155 \\
155\end{array}$ \\
\hline Amphipoda & $\begin{array}{l}\mathrm{DW}=0.172 \mathrm{~S}^{2.228} \\
\mathrm{AFDW}=0.116 \mathrm{~S}^{2.333}\end{array}$ & $\begin{array}{l}0.98 \\
0.97\end{array}$ & $\begin{array}{l}6 \\
6\end{array}$ & $\begin{array}{l}1109 \\
1109\end{array}$ \\
\hline Isopoda & $\begin{array}{l}\mathrm{DW}=0.209 \mathrm{~S}^{2.530} \\
\mathrm{AFDW}=0.117 \mathrm{~S}^{2.471}\end{array}$ & $\begin{array}{l}0.99 \\
0.99\end{array}$ & $\begin{array}{l}6 \\
6\end{array}$ & $\begin{array}{l}31 \\
31\end{array}$ \\
\hline Coleoptera & $\begin{array}{l}D W=0.135 \mathrm{~S}^{3.369} \\
A F D W=0.111 \mathrm{~S}^{3390}\end{array}$ & $\begin{array}{l}0.97 \\
0.98\end{array}$ & $\begin{array}{l}10 \\
10\end{array}$ & $\begin{array}{l}65 \\
65\end{array}$ \\
\hline Nereis diversicolor & $\begin{array}{l}\mathrm{DW}=1.534 \mathrm{~W}^{3.079} \\
\mathrm{AFDW}=1.299 \mathrm{~W}^{3.107}\end{array}$ & $\begin{array}{l}0.94 \\
0.94\end{array}$ & & $\begin{array}{l}24 \\
24\end{array}$ \\
\hline Capitella capitata ${ }^{a}$ & $\mathrm{DW}=0.517 \mathrm{~W}^{2.031}$ & 0.94 & & 25 \\
\hline Streblospio shrubsoli ${ }^{\mathrm{a}}$ & $\mathrm{DW}=1.358 \mathrm{~W}^{2.701}$ & 0.89 & & 23 \\
\hline Cerastoderma glaucum & $\begin{array}{l}D W=0.048 \mathrm{~L}^{3.141} \\
A F D W=0.006 \mathrm{~L}^{3244}\end{array}$ & $\begin{array}{l}0.98 \\
0.94\end{array}$ & & $\begin{array}{l}76 \\
72\end{array}$ \\
\hline Chironomidae & $\begin{array}{l}\mathrm{DW}=0.001 \mathrm{~L}^{2787} \\
\mathrm{AFDW}=0.001 \mathrm{~L}^{2.775}\end{array}$ & $\begin{array}{l}0.99 \\
0.99\end{array}$ & $\begin{array}{l}10 \\
10\end{array}$ & $\begin{array}{l}947 \\
947\end{array}$ \\
\hline
\end{tabular}


and the corresponding regression equations were calculated (Table 1). Thus, body length and width were converted to DW and AFDW for each sample.

To estimate the biomass corresponding to adults and juveniles, the sizes of adult and young individuals were fixed according to the life cycles of the species at this latitude

Estimation of production. The estimated production rates were calculated using the allometric equations provided by Edgar (1990a), which relate daily macrobenthic production $\left(P, \mu \mathrm{g} \mathrm{d}^{-1}\right)$ to $\operatorname{AFDW}(B, \mu \mathrm{g})$ and water temperature $\left(T,{ }^{\circ} \mathrm{C}\right)$, in ecosystems with water temperatures of 5 to $30^{\circ} \mathrm{C}$. For juveniles the equation used was $P=0.0063 B^{0.86} T^{0.80}$ and for aduits $P=$ $0.0050 B^{0.78} T^{0.92}$. As the sampling date was always one of the first days of each month, monthly $B$ and $T$ were calculated as the mean of the estimates of the month in question and for the following month.

Data analysis. For each sampling site and species, the total number of specimens caught in all the replicates and their estimated biomass (in g) were pooled by month and standardized for area sampled in order to give mean monthly abundances per $\mathrm{m}^{2}$.

Macroinvertebrate community structure was described each month on the basis of the following parameters: total density, number of species $(S)$, rarefied number of species $[E(S)]$ (Heck et al. 1975), mean number of species per replicate $(\bar{S})$, and the ShannonWiener $\left(H^{\prime}\right)$ and evenness $\left(J^{\prime}\right)$ indices (using $l n$ ) (Pielou 1966). Rarefaction was conducted using the computer program RAREFAC.BAS (Ludwig \& Reynolds 1988). The rarefied number of species, which is an estimate of the number of species that can be expected in a sample of a fixed size, allows comparisons of species numbers between communities when sample sizes (number of individuals) are not equal.

To discriminate the important environmental factors from those which have negligible effects on the abundance of the most abundant benthic macroinvertebrate species, correlation analyses (Pearson's r) were used. Monthly estimates of environmental factors at each sampling sites (and also excluding Site D) and the corresponding monthly mean densities $[\ln (1+$ no. of ind. $\mathrm{m}^{-2}$ ] of benthic macroinvertebrates were analysed. As the biomass of macroalgae was estimated for each replicate, this factor was not included the correlation analysis, but was used as covariate in performed ANCOVAs.

At sampling sites $A, B$ and $C, 1$-way ANCOVAs were performed to determine whether significant differences in benthic macroinvertebrate densities, species richness and evenness and diversity indices existed at different sampling dates and biomass of algal cover. Dry weight of macroalgae at each replicate was a continuous independent variable and date (month) was a categorical independent variable. Data were $\ln (x+1)$ transformed prior to analysis. Factors detected to be significant by ANCOVAs were further analysed using a posteriori Student-Newman-Keuls (SNK) tests set at the $5 \%$ significance level.

Two-way ANCOVAs were used to ascertain whether the densities of the most abundant species differed among sites, dates and biomass of algal cover. For this purpose, the number of individuals of a given species caught in each replicate was the dependent variable, dry weight of macroalgae was a continuous independent variable, and site ( $A$ and $C$ ) and date (month) were categorical independent variables. Continuous variables were subjected to a $\ln (x+1)$ transformation prior to analysis. Sites B and D, where the sampling period did not last an entire year, were left out.

A hierarchical ascending classification analysis (mean distance strategy) was performed on root-root transformed density data to determine similarity (BrayCurtis dissimilarity index) among samples. The cluster analysis was conducted using the computer program CA (Ludwig \& Reynolds 1988).

\section{RESULTS}

\section{Environmental conditions and vegetative cover}

Water temperatures at the sampling sites ranged from 11.5 to $24.3^{\circ} \mathrm{C}$, following a clear seasonal trend with minima occurring in December and January and maxima in August and September (Fig. 2). For each sampling date, differences among sampling stations in water temperature were never greater than $2^{\circ} \mathrm{C}$. Salinity also showed a seasonal pattern with minima in winter and maxima during the summer, ranging from 16.0 to $65.0 \%$ (Fig. 2), and with a maximum difference among sampling sites on any one occasion of $4 \%$ (between Sites A and C)

In the sediment, the clay fraction predominated at all the sampling sites, ranging from $89.3 \%$ at Site $D$ to $84.2 \%$ at Site $C$. Sites $B, C$ and D showed a slightly higher silt content than Site $A$, while Site $A$ had more sand than the other sites. Substratum porosity was very similar at Sites A, B and C, but lower at Site D. Sediment organic content showed similar values at all sampling sites (Table 2).

From February to April (gates open) the water level at Site $B$ was $\sim 0.10 \mathrm{~m}$, while Sites $A$ and $C$ were emerged during most of the time. Every fortnight, during $5 \mathrm{~d}$ on average, the sea water completely flooded the main water body at high spring tides $\left(6+6 \mathrm{~h} \mathrm{~d}^{-1}\right)$. During the other 9 mo the water level was quite constant $\left(-0.35,0.65\right.$ and $0.30 \mathrm{~m}$ at Sites $\mathrm{A}_{1}, \mathrm{~B}$ and $\mathrm{C}$ 
Fig. 2. Monthly water temperature, salinity, water level and algal cover biomass (mean dry weight $\pm 1 \mathrm{SE}$ ) at the 4 sampling sites

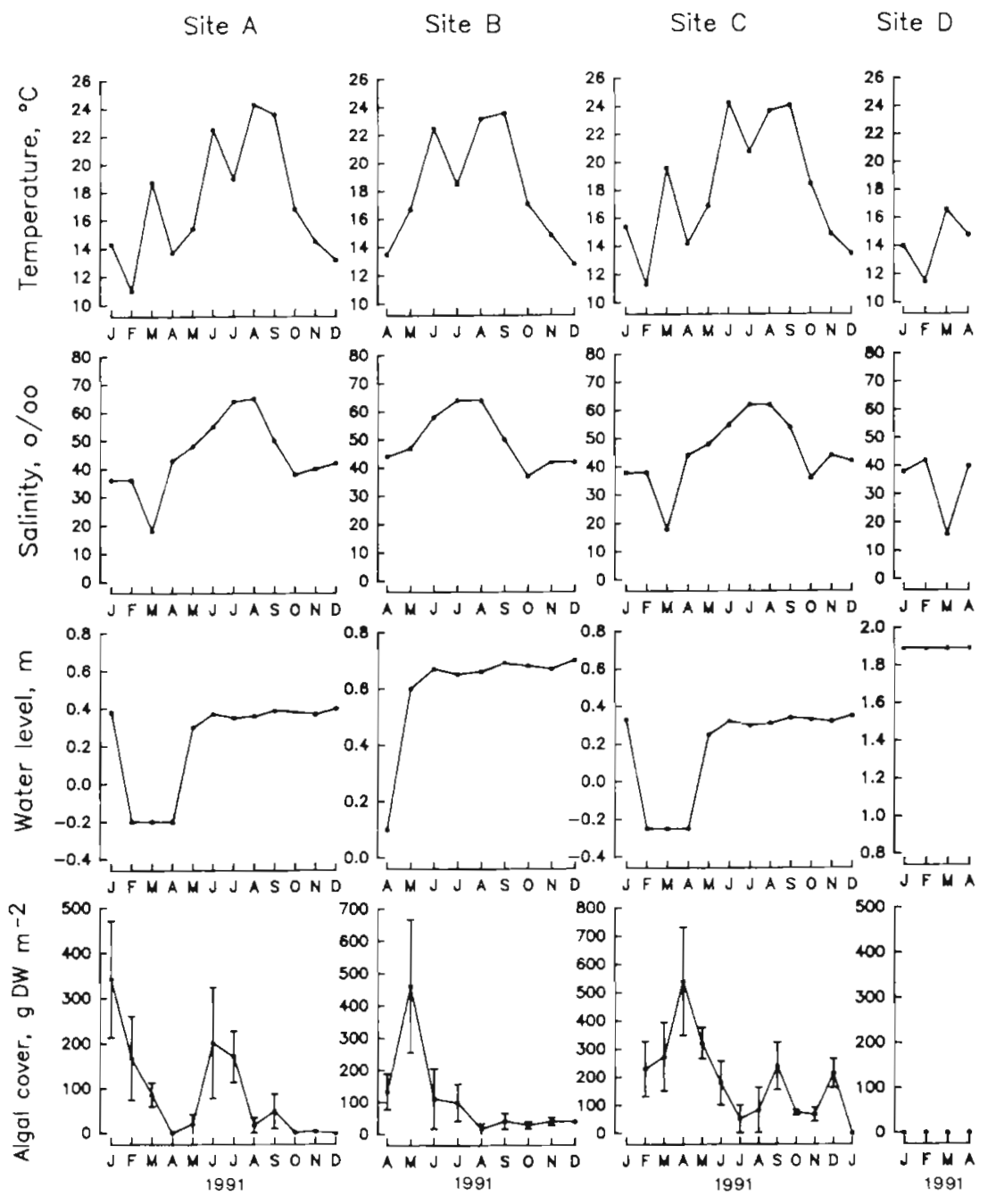

respectively). The height of the water column was greater but also constant at Site D ( $1.9 \mathrm{~m}$ ) (Fig. 2)

Algal cover was present at Sites A, B and C during most the year but never at Site $D$. Two species of macroalgae were dominant: Ulva lactuca at Sites A and $B$, and the filamentous Cladophora sp. at Site $C$; nevertheless Site B sometimes had stands of Clado-

Table 2. Sediment characteristics at the 4 sampling sites $x$ : mean

\begin{tabular}{|crrrrc|}
\hline Site & \multicolumn{2}{c}{ Composition (\%) } & Porosity & $\begin{array}{c}\% \text { Organic } \\
\text { matter }\end{array}$ \\
& $\geq 40 \mu \mathrm{m}$ & $<40-2 \mu \mathrm{m}$ & $<2 \mu \mathrm{m}$ & $x(\mathrm{SD})$ & $x(\mathrm{SD})$ \\
\hline $\mathrm{A}$ & 11.2 & 4.3 & 84.5 & $54.2(4.4)$ & $8.9(1.6)$ \\
$\mathrm{B}$ & 3.1 & 11.1 & 85.8 & $54.2(1.9)$ & $8.6(2.6)$ \\
$\mathrm{C}$ & 2.0 & 13.8 & 84.2 & $53.6(8.1)$ & $9.6(2.5)$ \\
D & 1.1 & 9.6 & 89.3 & $40.0(1.3)$ & $8.5(2.0)$ \\
a Data on organic matter were estimated during 1992 \\
\hline
\end{tabular}

phora sp. Algal biomass varied during the year with different numbers of peaks depending on the sampling site. Maximum values ( $>300 \mathrm{~g} \mathrm{~m}^{-2}$ ) were observed in winter at Site $A$, and in spring at Sites B and C (Fig. 2).

\section{Macroinvertebrate community composition and distribution}

A total of 29 species representing 16 orders of macroinvertebrate was recorded at the study location (Table 3). Faunal composition was very similar at Sites A, B and C with about $90 \%$ of species in common, but at Site D 3 of the 11 species sampled were exclusive to this sampling site.

Six species (Nereis diversicolor, Capitella capitata, Hydrobia minoricensis, $H$. ventrosa, Microdeutopus gryllotalpa and Chironomus salinarius) were numerically dominant in the main water body, and accounted for $95.6,98.0$ and $93.3 \%$ of individuals collected at 
Table 3. Mean densities $\left(D, \mathrm{~m}^{-2}\right)$, coefficient of variation $(\mathrm{CV}, \sigma / x)$ and in parentheses, the percentage contributed by different species to the total density of benthic macroinvertebrates at the 4 sampling sites. Number of species $(S)$, diversity $\left(H^{\prime}\right)$ and evenness $\left(J^{\prime}\right)$ at each sampling site are also recorded

\begin{tabular}{|c|c|c|c|c|c|c|c|c|c|c|c|c|}
\hline \multirow{2}{*}{$\begin{array}{l}\text { Order (Class) } \\
\text { Species }\end{array}$} & \multicolumn{3}{|c|}{ Site A } & \multicolumn{3}{|c|}{ Site B } & \multicolumn{3}{|c|}{ Site C } & \multicolumn{3}{|c|}{ Site D } \\
\hline & $D$ & $\mathrm{CV}$ & $(\%)$ & $D$ & CV & $(\%)$ & $D$ & $\mathrm{CV}$ & $(\%)$ & $D$ & $\mathrm{CV}$ & $(\%)$ \\
\hline \multicolumn{13}{|l|}{ Hoplonemertea (Nemertea) } \\
\hline $\begin{array}{l}\text { Tetrastemma melanocephalum } \\
\text { (Johnston) }\end{array}$ & 77.8 & 2.9 & $(0.4)$ & 39.5 & 1.3 & $(0.1)$ & 20.7 & 1.4 & $(0.1)$ & 14.8 & 1.3 & $(1.9)$ \\
\hline Nereiformes (Polychaeta) & & & & & & & & & & & & \\
\hline Nereis diversicolor Müller & 1460.6 & 1.2 & $(7.4)$ & 1748.2 & 0.8 & $(3.4)$ & 816.3 & 0.6 & $(2.3)$ & 101.8 & 0.9 & $(12.7)$ \\
\hline \multicolumn{13}{|l|}{ Spioniformes (Polychaeta) } \\
\hline Polydora sp. & 14.1 & 2.8 & $(0.1)$ & 61.7 & 2.8 & $(0.1)$ & 8.9 & 3.5 & $(0.0)$ & & - & \\
\hline Streblospio shrubsolid (Buchanan) & 155.9 & 1.8 & $(0.8)$ & 189.3 & 2.0 & $(0.4)$ & 1.5 & 3.5 & $(0.0)$ & 70.4 & 1.9 & (8.8) \\
\hline \multicolumn{13}{|l|}{ Capitelliformes (Polychaeta) } \\
\hline Capitella capitata (Fabricius) & 151.1 & 0.9 & $(0,8)$ & 366.2 & 1.3 & $(0.7)$ & 1415.6 & 1.5 & $(4.1)$ & & - & \\
\hline \multicolumn{13}{|l|}{ Tellinacea (Bivalvia) } \\
\hline Abra ovata (Philippi) & 61.7 & 1.2 & $(0.3)$ & 76.6 & 0.8 & $(0.1)$ & 28.2 & 1.6 & $(0.1)$ & 11.1 & 1.3 & $(1.4)$ \\
\hline \multicolumn{13}{|l|}{ Cardiacea (Bivalvia) } \\
\hline Cerastoderma glaucum Poiret & 136.3 & 1.9 & $(0.7)$ & 49.4 & 1.1 & $(0.1)$ & 220.0 & 1.4 & $(0.6)$ & 27.8 & 2.0 & (3.5) \\
\hline \multicolumn{13}{|l|}{ Monotocardia (Gastropoda) } \\
\hline Hydrobia minoricensis (Paladilhe) & 9476.1 & 0.9 & $(47.8)$ & 35259.2 & 0.7 & $(67.9)$ & 13335.9 & 0.4 & $(38.4)$ & 5.6 & 0.7 & $(0.7)$ \\
\hline Hydrobia ulvae (Pennat) & 387.8 & 1.6 & $(2.0)$ & 355.6 & 0.6 & $(0.7)$ & 289.8 & 0.8 & $(0.8)$ & 1.9 & 2.0 & $(0.2)$ \\
\hline Hydrobia ventrosa (Montagu) & 3305.9 & 0.91 & $(16.7)$ & 6708.7 & 0.9 & $(12.9)$ & 1863.1 & 0.3 & $(5.4)$ & & - & \\
\hline Rissoa parva (da Costa) & & - & & 1.6 & 3.0 & $(0.0)$ & 3.0 & 1.8 & $(0.0)$ & & - & \\
\hline \multicolumn{13}{|l|}{ Sacoglossa (Gastropoda) } \\
\hline Limapontia depressa Alder \& Hancoc & 1.5 & 2.3 & $(0.0)$ & 112.8 & 2.8 & $(0.2)$ & 0.7 & 3.5 & $(0.0)$ & & - & \\
\hline \multicolumn{13}{|l|}{ Nudibranchia (Gastropoda) } \\
\hline Stiliger bellulus (Orbigny) & & - & & 1.6 & 3.0 & $(0.0)$ & 0.7 & 3.5 & $(0.0)$ & & - & \\
\hline \multicolumn{13}{|l|}{ Mysidacea (Malacostracea) } \\
\hline Dyamisis bahirensis (Sars) & 11.9 & 3.5 & $(0.1)$ & 3.3 & 3.0 & $(0.0)$ & 13.3 & 3.3 & $(0.0)$ & & - & \\
\hline Schistomysis kervillei (Sars) & & - & & & - & & 0.7 & 3.5 & $(0.0)$ & & - & \\
\hline \multicolumn{13}{|l|}{ Cumacea (Malacostracea) } \\
\hline Iphinoe trispinosa (Goodsir) & & - & & & - & & & - & & 103.7 & 1.8 & $(13.0)$ \\
\hline \multicolumn{13}{|l|}{ Amphipoda (Malacostracea) } \\
\hline Corophium acherusicum Costa & & - & & & - & & & - & & 192.6 & 1.5 & (24.1) \\
\hline Microdeutopus gryllotalpa Costa & 4077.8 & 1.5 & $(20.6)$ & 4665.0 & 1.6 & $(9.0)$ & 4033.7 & 1.2 & $(11.6)$ & & - & \\
\hline \multicolumn{13}{|l|}{ Isopoda (Malacostracea) } \\
\hline Idotea chelipes (Pallas) & 0.7 & 3.5 & $(0.0)$ & & - & & & - & & & - & \\
\hline Lekanesphaera hookeri (Leach) & 1.5 & 2.3 & $(0.0)$ & 50.0 & 2.6 & $(0.1)$ & 10.0 & 1.4 & $(0.0)$ & & - & \\
\hline Paragnathia formica (Hesse) & & - & & & - & & & - & & 7.4 & 1.4 & $(0.9)$ \\
\hline \multicolumn{13}{|l|}{ Decapoda (Malacostracea) } \\
\hline Palaemonetes varians (Leach) & & - & & 46.9 & 2.9 & $(0.1)$ & 0.7 & 3.5 & $(0.0)$ & & - & \\
\hline Coleoptera (Insecta) & & & & & & & & & & & & \\
\hline Berosus spinosus (Steven) & & - & & & - & & 2.2 & 2.5 & $\{0.0\}$ & & - & \\
\hline Enochrus sp. & 3.0 & 3.0 & $(0.0)$ & & - & & 24.3 & 1.5 & $(0.1)$ & & - & \\
\hline Ochthebius sp. & & - & & & - & & 14.1 & 2.7 & $(0.0)$ & & - & \\
\hline Diptera (Insecta) & & & & & & & & & & & & \\
\hline Chironomus salinarius Kieffer & 494.1 & 0.9 & $(2.5)$ & 2133.3 & 1.0 & $(4.1)$ & 10952.2 & 0.9 & (31.5) & 263.0 & 1.1 & $(32.9)$ \\
\hline Halocladius spp..$^{a}$ & 22.2 & 1.8 & $(0.1)$ & 32.9 & 1.3 & $(0.1)$ & 1737.0 & 0.9 & $(5.0)$ & & - & \\
\hline Ephydra sp. & & - & & 2.5 & 2.8 & $(0.0)$ & 4.9 & 1.6 & $(0.0)$ & & - & \\
\hline Total density & 19840.1 & 0.8 & & 51912.3 & 0.7 & & 34800.8 & & & 800.1 & 0.8 & \\
\hline Number of species $(S)$ & 18 & & & 20 & & & 21 & & & 11 & & \\
\hline Evenness index $\left(J^{\prime}\right)$ & 0.57 & 0.2 & & 0.42 & 0.2 & & 0.53 & 0.2 & & 0.76 & 0.2 & \\
\hline Diversity index $\left(H^{\prime}\right)$ & 1.33 & 0.2 & & 1.02 & 0.3 & & 1.33 & 0.2 & & 1.46 & 0.2 & \\
\hline
\end{tabular}


Fig. 3. Monthly macroinvertebrate mean density $(D$, ind $m^{-2}$ ), number of species ( $S$ ), rarefied number of species $[E(S)]$, mean number of species $(\bar{S})$ per replicate $\left(0.0225 \mathrm{~m}^{2}\right)$ and mean diversity $\left(H^{\prime}\right)$ and evenness $\left(J^{\prime}\right)$ indices at Sites A, B and C. (Values are $\pm 1 \mathrm{SE}$ )
Site A
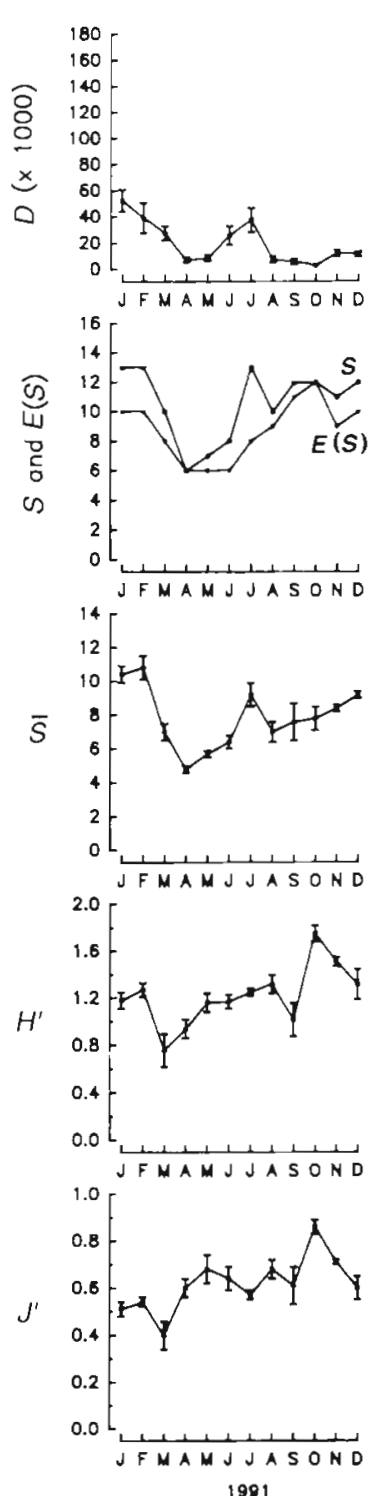

Site $B$
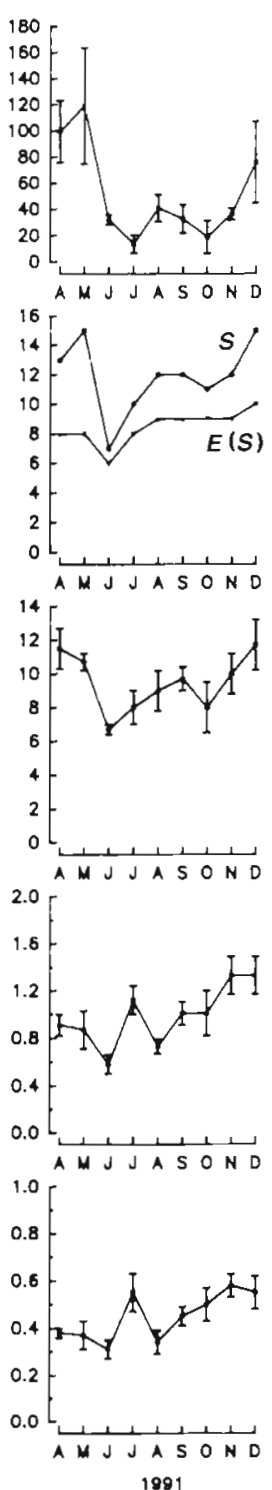

Site C

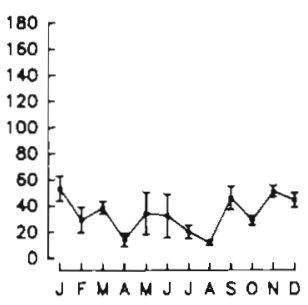

$16-$
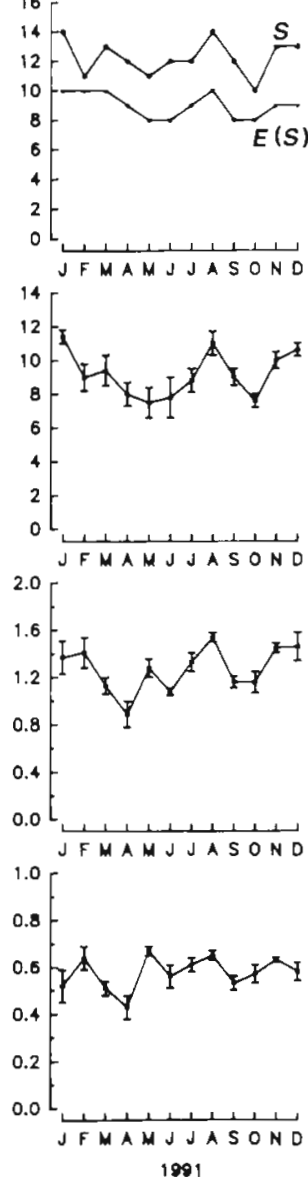

Sites A, B and C respectively. At Site D, 5 species $(N$. diversicolor, Streblospio shrubsolii, Iphinoe trispinosa, Corophium acherusicum and C. salinarius) constituted $91.5 \%$ of the total number of invertebrates.

The highest mean total density of macroinvertebrates was found at Site B (51912.3 ind. $\mathrm{m}^{-2}$ ) and the lowest at Site D (800.1 ind. $\left.\mathrm{m}^{-2}\right)$. Differences in density between Site D and the other 3 sites were always significant, but in the main water body only mean densities at Site $A$ and $B$ were significantly different (1-way ANOVA; SNK test, $\mathrm{p}<0.05)$. Conversely, Sites $B$ and $\mathrm{D}$, respectively, had the lowest $\left(H^{\prime}=1.02, J^{\prime}=0.42\right)$ and highest $\left(H^{\prime}=1.46, J^{\prime}=0.76\right)$ values of diversity and evenness indices (Table 3). Differences of the diversity index $\left(H^{\prime}\right)$ were only significant between Sites B and
D, while evenness indices were always significantly different between sites, except between Sites $A$ and $C$ (1-way ANOVA; SNK test, $p<0.05)$.

\section{Temporal trends in total number of individuals and species}

Monthly estimates of total macroinvertebrate density showed considerable seasonal variation at Sites $\mathrm{A}, \mathrm{B}$ and $C$ (Fig. 3, Table 4) (Site D was excluded due to the short duration of sampling). A main annual peak of density was observed in winter at Sites $A$ and $C$, and in spring at Site B. There was a significant positive correlation between total density and the biomass of algal 
Table 4. Mean squares (MS) and significance level $(\mathrm{p})$ for 1 -way ANCOVAs $[\ln (x+1)$-transformed data and the total density of benthic macroinvertebrates $(D)$, number of species per replicate $(\bar{S})$, evenness $\left(J^{\prime}\right)$ and diversity $\left(H^{\prime}\right)$ indices at $S i t e s$ A, B and $C$. Date was the categorical variable and the dry weight of macroalgae (DW) in each replicate was the continuous variable. Mean values of the dependent variables in months joined by underline were not significantly different at $5 \%$ level using StudentNewman-Keuls test. $r$ : covariate coefficient; df: degree of freedom; ns: no significant differences. Month codes: A1, A2, ..., A12, January to December at Site A, etc.

\begin{tabular}{|c|c|c|c|c|c|c|}
\hline \multirow[t]{2}{*}{ Variable } & \multicolumn{3}{|c|}{$\begin{array}{l}\text { Covariate } \\
\text { DW }(1 \mathrm{df})\end{array}$} & \multicolumn{2}{|c|}{$\begin{array}{c}\text { Factor } \\
\text { Date (11 df) }\end{array}$} & \multirow[t]{2}{*}{ Months } \\
\hline & MS & $\mathrm{p}$ & $\mathrm{r}$ & MS & $\mathrm{p}$ & \\
\hline \multicolumn{7}{|l|}{ Site A } \\
\hline$D$ & 6.53 & $<0.01$ & 0.70 & 1.78 & $<0.01$ & A10 A9 A8 A4 A5 A11 A12 A6 A3 A7 A2 A1 \\
\hline $\bar{S}$ & 0.03 & ns & 0.31 & 0.19 & $<0.01$ & A4 A5 A6 A8 A3 A9 A10 A11 A7 A12 A1 A2 \\
\hline$J^{\prime}$ & 0.00 & ns & -0.30 & 0.03 & $<0.01$ & A3 A 1 A2 A7 A12 A4 A9 A6 A5 A8 A11 A10 \\
\hline$H^{\prime}$ & 0.00 & ns & -0.12 & 0.07 & $<0.01$ & A3 A4 A9 A5 A6 A. A7 A2 A12 A8 A 11 A 10 \\
\hline \multicolumn{7}{|l|}{ Site B } \\
\hline$D$ & 0.78 & $<0.05$ & 0.60 & 1.78 & $<0.05$ & B7 B10 B9 B6 B11 B8 B12 B4 B5 \\
\hline $\bar{S}$ & 0.00 & ns & 0.43 & 0.08 & ns & B6 B10 B7 B8 B9 B11 B5 B4 B12 \\
\hline$J^{\prime}$ & 0.00 & ns & 0.00 & 0.01 & $<0.05$ & B6 B8 B5 B4 B9 B10 B7 B12 B11 \\
\hline$H^{\prime}$ & 0.03 & ns & 0.15 & 0.05 & $<0.01$ & $\mathrm{~B} 6 \mathrm{~B} 8 \mathrm{~B} 5 \mathrm{~B} 4 \mathrm{~B} 10 \mathrm{~B} 9 \mathrm{~B} 7 \mathrm{~B} 12 \mathrm{~B} 11$ \\
\hline \multicolumn{7}{|l|}{ Site $C$} \\
\hline$D$ & 4.03 & $<0.01$ & 0.37 & 1.27 & $<0.01$ & $\mathrm{C} 4 \mathrm{C} 2 \mathrm{C} 8 \mathrm{C} 5 \mathrm{C} 7 \mathrm{C} 3 \mathrm{C} 6 \mathrm{C} 10 \mathrm{C} 11 \mathrm{C} 1 \mathrm{C} 9 \mathrm{C} 12$ \\
\hline $\bar{S}$ & 0.27 & $<0.01$ & 0.36 & 0.09 & $<0.01$ & $\mathrm{C} 4 \mathrm{C} 5 \mathrm{C} 10 \mathrm{C} 6 \mathrm{C} 3 \mathrm{C} 2 \mathrm{C} 9 \mathrm{C} 7 \mathrm{C} 11 \mathrm{C} 8 \mathrm{C} 1 \mathrm{C} 12$ \\
\hline$J^{\prime}$ & 0.02 & $<0.05$ & -0.33 & 0.01 & $<0.01$ & $\mathrm{C} 4 \mathrm{C} 1 \mathrm{C} 9 \mathrm{C} 6 \mathrm{C} 3 \mathrm{C} 12 \mathrm{C} 10 \mathrm{C} 7 \mathrm{C} 11 \mathrm{C} 2 \mathrm{C} 8 \mathrm{C} 5$ \\
\hline$H^{\prime}$ & 0.00 & ns & -0.10 & 0.04 & $<0.01$ & $\mathrm{C} 4 \mathrm{C} 6 \mathrm{C} 3 \mathrm{C} 10 \mathrm{C} 9 \mathrm{C} 7 \mathrm{C} 4 \mathrm{C} 1 \mathrm{C} 2 \mathrm{C} 11 \mathrm{C} 12 \mathrm{C} 8$ \\
\hline
\end{tabular}

cover at Sites A (ANCOVA, $p<0.01), B(p<0.05)$ and $\mathrm{C}(\mathrm{p}<0.01)$.

The number of species $(S)$ caught each month at each site ranged from 6 at Site A. (April) to 15 at Site B (May and December), while $E(S)$ showed smaller variation (6 to 12) (Fig. 3). This last parameter displayed a seasonal pattern at Site $\mathrm{A}$, reaching a peak in October (12) and falling to the lowest value (6) from April to June. It showed smaller variation at Site B, from 6 (June) to 10 (December). In contrast, the rarefied number of species did not display a seasonal trend at Site C. ranging only between 8 and $10 . \bar{S}$, which showed a similar seasonal pattern to $S$, was significantly higher in winter than in spring at Sites $\mathrm{A}$ and $\mathrm{C}$ (Fig. 3). Despite the considerable variation shown by $\bar{S}$ at Site B, their monthly differences were not significant (Table 4). At Site $C$ there was a positive correlation (ANCOVA, $\mathrm{p}<0.01$ ) between $\bar{S}$ and the biomass of algal cover.

$H^{\prime}$ and $J^{\prime}$ were low, and ranged from 0.58 and 0.30 respectively (June, at Site B) to 1.85 and 0.75 respec- tively (October, at Site A) (Fig. 3). Both diversity parameters showed a very similar seasonal pattern of variation within each site. Thus, $H^{\prime}$ and $J^{\prime}$ indices were significantly lower in March than in autumn at Site A and in June than in late autumn at Site B (ANCOVAs; SNK test, $\mathrm{p}<0.05$ ). In contrast, both indices did not display a clear seasonal trend at Site $C$, although there were significant differences between some monthly samples (Table 4). The $J^{\prime}$ was negatively correlated with the biomass of macroalgae at Site C (ANCOVA, $\mathrm{p}<0.05$ ).

\section{Seasonality and distribution of the most abundant species}

There was large seasonal variation in the density of individual species, both within and among sites. The polychaetes Nereis diversicolor and Capitella capitata (most abundant at Site C) reached a maximum in late autumn-early winter (Fig. 4). 


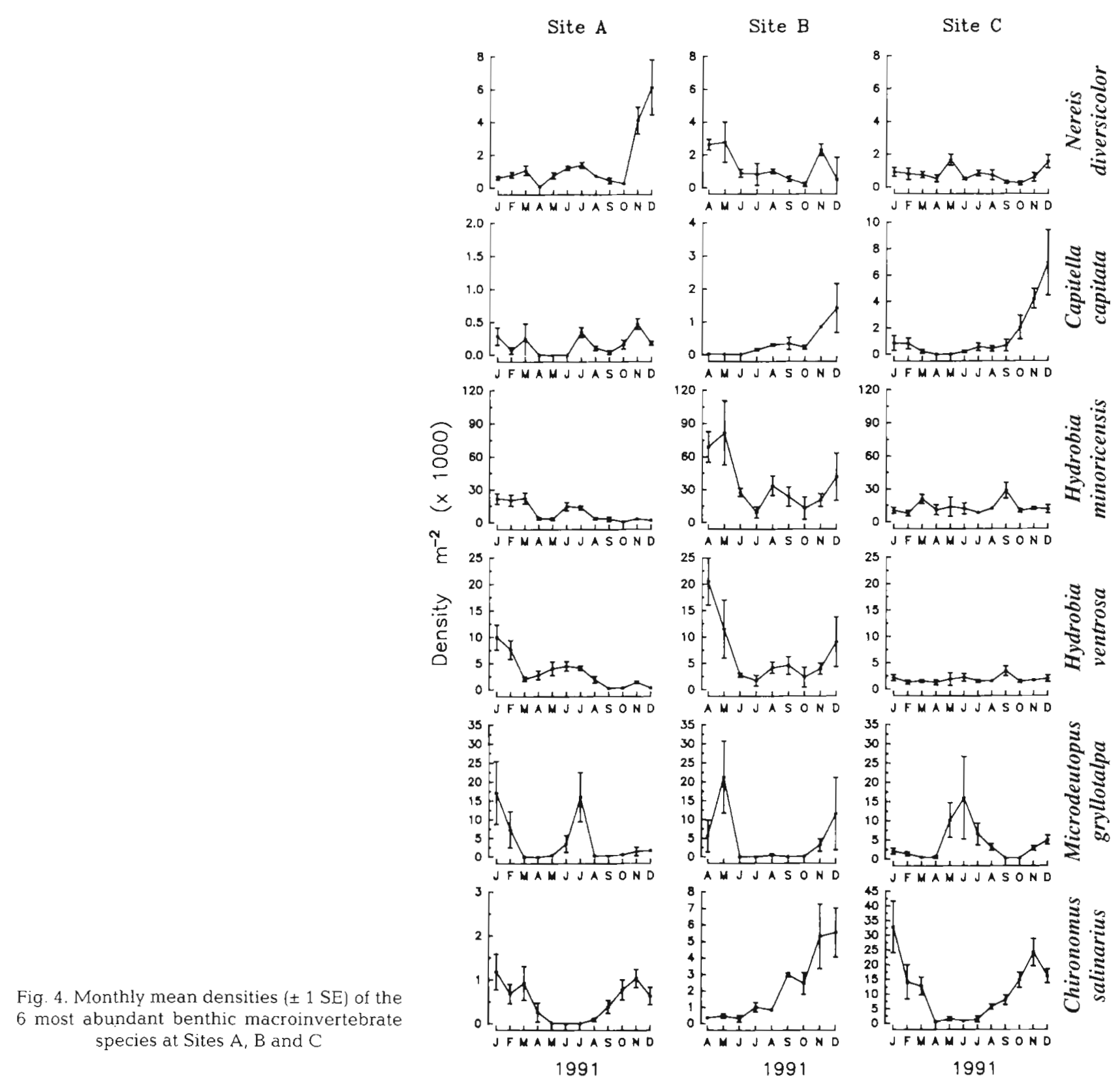

The gastropods Hydrobia minoricensis and $H$. ventrosa, which were most abundant at Sites A and B, seemed to display 2 annual peaks in abundance, in winter-early spring and in summer. The amphipod Microdeutopus gryllotalpa also showed 2 annual peaks, this time in late spring-early summer and in late autumn - winter. Finally, larvae of Chironomus salinarius, very abundant at Site $C$, increased in numbers from late summer through winter at this site (Fig. 4).

At Sites $A$ and $C$, where the sampling period lasted an entire year, 2-way ANCOVAs showed that the density of each of the 6 most abundant species differed significantly amongst Dates, and that the Site $\times$ Date interaction term was significant ( $p<0.01$, Table 5), indicating that intersite differences changed seasonally. Furthermore, the density of 3 of the species (Capitella capitata, Hydrobia minoricensis and Chironomus salinarius) differed significantly between sites $(p<0.01)$. Finally, the abundances of the species $H$. minoricensis, $H$. ventrosa, Microdeutopus gryllotalpa and $C$. salinarius were positively related and the abundance of Nereis diversicolor negatively related $(\mathrm{p}<0.01)$ to the biomass of macroalgae present in each replicate (Table 5 ).

The correlation coefficients between the density of the most abundant species and some environmental 
Table 5. Mean squares (MS) and significance level (p) for ANCOVAs $\left[\ln \left(1+\right.\right.$ no. of ind per $0.0225 \mathrm{~m}^{2}$ sample)] of the $6 \mathrm{most}$ abundant macroinvertebrate species at Sites $A$ and C. Site (St) and Date (D) were categorical variables and the dry weight of macroalgae $[\ln (1+D W)]$ in each replicate was the continuous variable. For each species mean densities in months joined by underline were not significantly different at $5 \%$ level using Student-Newman-Keuls test. $r$ : covariate coefficient; df: degrees of freedom; ns: no significant differences. Month codes: A1, A2, ... A12, January to December at Site A, etc

\begin{tabular}{|c|c|c|c|c|c|c|c|c|c|c|}
\hline \multirow[t]{3}{*}{ Species } & \multirow{2}{*}{\multicolumn{3}{|c|}{$\begin{array}{l}\text { Covariate } \\
\text { DW }(1 \text { df })\end{array}$}} & \multicolumn{4}{|c|}{ Main effects } & \multirow{2}{*}{\multicolumn{2}{|c|}{$\begin{array}{l}\text { Interactions } \\
\text { St } \times D(11 d f)\end{array}$}} & \multirow{3}{*}{$\begin{array}{c}\text { Residu } \\
\text { (93 df) } \\
\text { MS }\end{array}$} \\
\hline & & & & \multicolumn{2}{|c|}{ Site $(1 \mathrm{df})$} & \multicolumn{2}{|c|}{ Date (11 df) } & & & \\
\hline & MS & $\mathrm{p}$ & $\mathrm{r}$ & MS & $\mathrm{p}$ & MS & $\mathrm{p}$ & MS & $\mathrm{p}$ & \\
\hline Nereis diversicolor & 3.82 & $<0.01$ & -0.23 & 1.38 & ns & 5.21 & $<0.01$ & 2.08 & $<0.01$ & 0.49 \\
\hline Capitella capitata & 0.39 & ns & 0.02 & 35.47 & $<0.01$ & 11.04 & $<0.01$ & 2.49 & $<0.01$ & 0.92 \\
\hline Hydrobia minoricensis & 46.37 & $<0.01$ & 0.35 & 8.05 & $<0.01$ & 2.06 & $<0.01$ & 4.37 & $<0.01$ & 0.67 \\
\hline$H$ ventrosa & 13.54 & $<0.01$ & 0.30 & 2.34 & $<0.05$ & 2.34 & $<0.01$ & 4.89 & $<0.01$ & 0.51 \\
\hline Microdeutopus gryllotalpa & 46.58 & $<0.01$ & 0.84 & 0.64 & ns & 20.77 & $<0.01$ & 5.30 & $<0.01$ & 1.29 \\
\hline Chironomus salinarius & 59.93 & $<0.01$ & 0.50 & 153.66 & $<0.01$ & 22.14 & $<0.01$ & 2.13 & $<0.01$ & 0.63 \\
\hline Nereis diversicolor & \multicolumn{10}{|c|}{ A4 C10 A9 A10 C9 C6 C4 C11 A5 A8 A1 C7 C8 C2 A2 C1 A3 C3 C12 A6 A7 C5 A11 A12 } \\
\hline Capitella capitata & \multicolumn{10}{|c|}{ C5 A6 A4 A5 C4 A9 A2 A3 A8 A10 C3 C6 A12 A1 C8 C7 A7 C2 C9 C1 A11 C10 C11 C12 } \\
\hline Hydrobia minoricensis & \multicolumn{10}{|c|}{$\mathrm{A} 9 \mathrm{~A} 10 \mathrm{~A} 12 \mathrm{~A} 8 \mathrm{~A} 5 \mathrm{~A} 11 \mathrm{~A} 4 \mathrm{C} 5 \mathrm{C} 2 \mathrm{C} 6 \mathrm{C} 7 \mathrm{C} 4 \mathrm{C} 1 \mathrm{C} 12 \mathrm{C} 10 \mathrm{C} 11 \mathrm{C} 8 \mathrm{~A} 6 \mathrm{~A} 7 \mathrm{~A} 2 \mathrm{~A} 1 \mathrm{C} 3 \mathrm{~A} 3 \mathrm{C} 9$} \\
\hline$H$. ventrosa & \multicolumn{10}{|c|}{ A9 A12 A $10 \mathrm{C} 5 \mathrm{C} 4 \mathrm{C} 2 \mathrm{C} 3 \mathrm{C} 8 \mathrm{C} 11 \mathrm{C} 10 \mathrm{~A} 8 \mathrm{C} 7 \mathrm{C} 1 \mathrm{~A} 11 \mathrm{C} 12 \mathrm{~A} 3 \mathrm{C} 6 \mathrm{C} 9 \mathrm{~A} 4 \mathrm{~A} 7 \mathrm{~A} 6 \mathrm{~A} 5 \mathrm{~A} 2 \mathrm{~A} 1$} \\
\hline Microdeutopus gryllotalpa & \multicolumn{10}{|c|}{ A3 C4 A4 C3 C10 C9 C2 A9 A8 A5 C1 A11 A6 A10 C8 C11 A2 A7 A12 C5 A 1 C12 C7 C6 } \\
\hline \multirow[t]{2}{*}{ Chironomus salinarius } & \multicolumn{10}{|c|}{ A6 A7 A5 C4 A4 A8 C5 A9 A2 A3 A1 C7 C6 A12 A10 A11 C8 C2 C3 C9 C11 C10 C12 C1 } \\
\hline & & & & & & & $\equiv$ & & & \\
\hline
\end{tabular}

factors are shown in Table 6. The water temperature and salinity were not significantly correlated with the density of these species, except the water salinity and the density of Chironomus salinarius $(p<0.05)$ within the main water body. The water level was negatively correlated with the density of the 6 most abundant species, due to the low macrofaunal density at Site $D$, so there was not significant correlation between both variables within the main water body (Sites A, B and $C$ ). Finally, the density of $C$. salinarius and the silt con-

Table 6. Results of correlation analyses of monthly densities $\left[\operatorname{In}\left(1+\right.\right.$ no. of ind. $\left.\left.\mathrm{m}^{-2}\right)\right]$ of the 6 most abundant macroinvertebrates species and monthly estimates of some environmental factors at the 4 sampling sites $(n=37)$ and, in parentheses, excluding samples from Site $D(n=33)$. r: correlation coefficient; $p$ : significance level; ns: no significant correlation

\begin{tabular}{|c|c|c|c|c|c|c|c|c|}
\hline \multirow[t]{2}{*}{ Species } & \multicolumn{2}{|c|}{ Temperature $\left({ }^{\circ} \mathrm{C}\right)$} & \multicolumn{2}{|c|}{ Salinity (\%o) } & \multicolumn{2}{|c|}{ Water level $(\mathrm{cm})$} & \multicolumn{2}{|c|}{ Silt content ( $\%$ dry wt) } \\
\hline & r & $\mathrm{p}$ & $r$ & p & $\mathrm{r}$ & p & r & $\mathrm{p}$ \\
\hline Nereis diversicolor & $\begin{array}{l}-0.01 \\
(-0.26)\end{array}$ & $\begin{array}{c}\text { ns } \\
\text { (ns) }\end{array}$ & $\begin{array}{c}0.18 \\
(0.01)\end{array}$ & $\begin{array}{l}\text { ns } \\
\text { (ns) }\end{array}$ & $\begin{array}{c}-0.63 \\
(0.23)\end{array}$ & $\begin{array}{c}<0.01 \\
(\mathrm{~ns})\end{array}$ & $\begin{array}{l}-0.02 \\
(-0.03)\end{array}$ & $\begin{array}{l}\mathrm{ns} \\
\text { (ns) }\end{array}$ \\
\hline Capitella capitata & $\begin{array}{c}0.10 \\
(-0.07)\end{array}$ & $\begin{array}{c}\text { ns } \\
\text { (ns) }\end{array}$ & $\begin{array}{c}0.04 \\
(-0.17)\end{array}$ & $\begin{array}{l}\text { ns } \\
\text { (ns) }\end{array}$ & $\begin{array}{l}-0.53 \\
(0.15)\end{array}$ & $\begin{array}{c}<0.01 \\
\text { (ns) }\end{array}$ & $\begin{array}{c}0.28 \\
(0.33)\end{array}$ & $\begin{array}{c}\mathrm{ns} \\
\text { (ns) }\end{array}$ \\
\hline Hydrobia minoricensis & $\begin{array}{c}0.28 \\
(0.06)\end{array}$ & $\begin{array}{c}\text { ns } \\
\text { (ns) }\end{array}$ & $\begin{array}{c}0.27 \\
(-0.01)\end{array}$ & $\begin{array}{l}\text { ns } \\
\text { (ns) }\end{array}$ & $\begin{array}{c}-0.89 \\
(0.12)\end{array}$ & $\begin{array}{c}<0.01 \\
\text { (ns) }\end{array}$ & $\begin{array}{c}0.17 \\
(0.44)\end{array}$ & $\begin{array}{c}\text { ns } \\
(<0.05)\end{array}$ \\
\hline Hydrobia ventrosa & $\begin{array}{c}0.18 \\
(-0.22)\end{array}$ & $\begin{array}{c}\text { ns } \\
\text { (ns) }\end{array}$ & $\begin{array}{c}0.30 \\
(0.02)\end{array}$ & $\begin{array}{c}\text { ns } \\
\text { [ns] }\end{array}$ & $\begin{array}{c}-0.93 \\
(0.12)\end{array}$ & $\begin{array}{l}<0.01 \\
\text { (ns) }\end{array}$ & $\begin{array}{c}0.04 \\
(-0.12)\end{array}$ & $\begin{array}{l}\mathrm{ns} \\
\text { (ns) }\end{array}$ \\
\hline Microdeutopus gryllotalpa & $\begin{array}{c}0.05 \\
(-0.22)\end{array}$ & $\begin{array}{l}\text { ns } \\
\text { (ns) }\end{array}$ & $\begin{array}{c}0.28 \\
(0.12)\end{array}$ & $\begin{array}{l}\text { ns } \\
\text { (ns) }\end{array}$ & $\begin{array}{c}-0.63 \\
(0.10)\end{array}$ & $\begin{array}{c}<0.01 \\
(\mathrm{~ns})\end{array}$ & $\begin{array}{c}0.12 \\
(0.16)\end{array}$ & $\begin{array}{l}\mathrm{ns} \\
\text { (ns) }\end{array}$ \\
\hline Chironomus salinarius & $\begin{array}{l}-0.11 \\
(-0.20)\end{array}$ & $\begin{array}{l}\mathrm{ns} \\
\text { (ns) }\end{array}$ & $\begin{array}{l}-0.26 \\
(-0.39)\end{array}$ & $\begin{array}{c}n s \\
(<0.05)\end{array}$ & $\begin{array}{l}-0.26 \\
(-0.02)\end{array}$ & $\begin{array}{l}\text { ns } \\
\text { (ns) }\end{array}$ & $\begin{array}{c}0.63 \\
(0.66)\end{array}$ & $\begin{array}{l}<0.01 \\
(<0.01)\end{array}$ \\
\hline
\end{tabular}


tent on the sediment were always positively correlated $(\mathrm{p}<0.01)$, while for Hydrobia minoricensis this correlation was only significant within the main water body $(p<$ 0.05).

\section{Similarities of samples}

Two major clusters were separated by the classification analysis (Fig. 5), constrasting monthly samples from Sites A, B and C (Group I) with samples from Site D (Group II). Within Group I, cluster Z included samples from Site C (July to March), 2 subclusters containing samples from summerautumn (Z1) and winter samples (Z2). Cluster W contained samples from Sites A and B, as well as the single sample from December at Site C (C12). Within this cluster, samples from summer - early autumn (W1) and samples from late autumn - winter (W2), formed 2 smaller clusters. Group I also included spring and early summer samples from Sites A, B and $\mathrm{C}(\mathrm{V}$ and $\mathrm{X})$ that showed higher intersample heterogeneity.

\section{Macroinvertebrate biomass and production}

Mean annual biomass of the macroinvertebrate community was highest at Site B and lowest at Site A, in terms of both DW and AFDW, but differences among sites were not significant for AFDW (1-way ANOVA; SNK test, $p>0.05$ ). Gastropods, bivalves and polychaetes made the greatest contribution to the annual macroinvertebrate DW, together representing between $97.8 \%$ (Site B) and $87.4 \%$ (Site C) of total DW (Table 7). In terms of AFDW the situation was similar, but at Site C Diptera also made an important contribution $(22.3 \%)$. In these 4 main taxonomic groups, Hydrobia minoricensis (gastropod), Cerastoderma glaucum (bivalve), Nereis diversicolor (polychaete) and Chironomus salinarius (chironomid) were the most important species in terms of biomass. The intersite differences of the biomass (DW and AFDW) of polychaetes and amphipods were not significant. In contrast, the biomass of gastropods and bivalves were higher at Site B, while the biomass of diptera was greater at Site $C$ (SNK test, $p<0.05$ ). The high coefficient of variation of DW and AFDW observed for the different taxonomic groups is evidence for important seasonal variations in biomass (Table 7).

Total annual production in terms of AFDW ranged between $13.3 \mathrm{~g} \mathrm{~m}^{-2} \mathrm{yr}^{-1}$ at Site A and $27.33 \mathrm{~g} \mathrm{~m}^{-2} \mathrm{yr}^{-1}$
Table 7. Annual mean biomass $\left(B, \mathrm{~g} \mathrm{~m}^{-2}\right)$, coefficient of variation $(C V, \sigma / x)$ and relative contribution $(\%)$ of the most abundant invertebrate taxa at each study site. Mean biomass underlined were not significantly different at level $5 \%$ using Student-Newman-Keuls test on In-transformed data (1-way ANOVA, Factor $=$ Site). DW: dry weight. AFDW: ash-free dry weight

\begin{tabular}{|c|c|c|c|c|c|c|}
\hline \multirow[t]{2}{*}{ Class } & \multicolumn{3}{|c|}{ DW } & \multicolumn{3}{|c|}{ AFDW } \\
\hline & Site: A & B & $\mathrm{C}$ & $A$ & $\mathrm{~B}$ & $\mathrm{C}$ \\
\hline \multicolumn{7}{|c|}{ Polychaeta } \\
\hline$B$ & 4.08 & 8.01 & 7.79 & 3.52 & 7.90 & 6.83 \\
\hline $\mathrm{CV}$ & 0.89 & 0.39 & 1.29 & 0.90 & 0.37 & 1.29 \\
\hline$\%$ & 9.67 & 7.66 & 13.48 & 33.15 & 31.21 & 35.54 \\
\hline \multicolumn{7}{|l|}{ Bivalvia } \\
\hline$B$ & 10.90 & 29.04 & 14.81 & 1.78 & 5.10 & $\underline{2.45}$ \\
\hline $\mathrm{CV}$ & 1.42 & 0.93 & 1.22 & $\overline{1.42}$ & 0.92 & $\overline{1.21}$ \\
\hline$\%$ & 25.82 & 27.77 & 25.63 & 16.76 & 20.15 & 12.75 \\
\hline \multicolumn{7}{|c|}{ Gastropoda } \\
\hline$B$ & 25.86 & 65.18 & 28.47 & $\underline{4.35}$ & 10.60 & 4.77 \\
\hline $\mathrm{CV}$ & 0.87 & 0.79 & 0.41 & 0.83 & 0.77 & 0.40 \\
\hline$\%$ & 61.27 & 62.34 & 49.26 & 40.96 & 41.88 & 24.82 \\
\hline \multicolumn{7}{|c|}{ Amphipoda } \\
\hline$B$ & $\underline{1.18}$ & $\underline{1.17}$ & $\underline{1.16}$ & $\underline{0.81}$ & $\underline{0.80}$ & $\underline{0.79}$ \\
\hline $\mathrm{CV}$ & 1.67 & 1.72 & 0.98 & 1.68 & 1.72 & 0.99 \\
\hline$\%$ & 2.80 & 1.12 & 2.01 & 7.63 & 3.16 & 4.11 \\
\hline \multicolumn{7}{|l|}{ Diptera } \\
\hline$B$ & 0.17 & 1.14 & 5.44 & 0.13 & 0.90 & 4.30 \\
\hline $\mathrm{CV}$ & $\overline{0.81}$ & 0.85 & 1.02 & 0.82 & 0.85 & 1.02 \\
\hline$\%$ & 0.40 & 1.09 & 9.41 & 1.22 & 3.56 & 22.37 \\
\hline \multicolumn{7}{|c|}{ Other groups } \\
\hline$B$ & 0.03 & $\underline{0.01}$ & 0.12 & $\underline{0.02}$ & 0.01 & 0.09 \\
\hline $\mathrm{CV}$ & 1.57 & 1.80 & 1.57 & 1.27 & 1.75 & 1.60 \\
\hline$\%$ & 0.07 & 0.01 & 0.21 & 0.19 & 0.04 & 0.47 \\
\hline Total $B$ & 42.22 & 104.56 & 57.79 & 10.62 & 25.31 & 19.22 \\
\hline
\end{tabular}


Table 8. Monthly biomass (AFDW, $\mathrm{g} \mathrm{m}^{-2}$ ), water temperature $\left(T,{ }^{\circ} \mathrm{C}\right.$ ) and production $\left(P, \mathrm{AFDW}, \mathrm{g} \mathrm{m}^{-2}\right.$ ) of the macroinvertebrate community at Sites $A, B$ and C. Juv.: juveniles; Adu.: adults

\begin{tabular}{|c|c|c|c|c|c|c|c|c|c|c|c|c|}
\hline \multirow[t]{3}{*}{ Month } & \multicolumn{4}{|c|}{ Site A } & \multicolumn{4}{|c|}{ Site B } & \multicolumn{4}{|c|}{ Site C } \\
\hline & \multicolumn{2}{|c|}{ Biomass } & \multirow[t]{2}{*}{$T$} & \multirow{2}{*}{$P$} & \multicolumn{2}{|c|}{ Biomass } & \multirow{2}{*}{$T$} & \multirow{2}{*}{$p$} & \multicolumn{2}{|c|}{ Biomass } & \multirow{2}{*}{$T$} & \multirow[t]{2}{*}{$P$} \\
\hline & Adu. & Juv. & & & Adu. & Juv. & & & Adu. & Juv. & & \\
\hline Jan & 14.91 & 7.11 & 12.9 & 1.82 & & & & & 6.90 & 17.63 & 12.9 & 2.93 \\
\hline Feb & 13.37 & 3.57 & 15.1 & 1.28 & & & & & 7.66 & 12.96 & 15.1 & 2.42 \\
\hline Mar & 5.44 & 1.71 & 16.1 & 0.77 & & & & & 5.77 & 5.78 & 16.1 & 1.55 \\
\hline Apr & 1.93 & 0.69 & 14.4 & 0.30 & 28.79 & 11.56 & 15.1 & 3.17 & 19.61 & 1.69 & 15.2 & 1.27 \\
\hline May & 6.37 & 1.48 & 19.0 & 0.89 & 23.56 & 9.20 & 19.6 & 3.41 & 22.46 & 2.00 & 20.6 & 1.94 \\
\hline Jun & 12.05 & 3.90 & 20.8 & 1.81 & 15.64 & 4.96 & 20.5 & 2.20 & 8.13 & 2.84 & 22.6 & 1.46 \\
\hline Jul & 9.60 & 3.36 & 21.7 & 1.67 & 13.39 & 4.67 & 20.9 & 2.13 & 17.33 & 5.63 & 22.3 & 2.69 \\
\hline Aug & 7.37 & 1.33 & 23.9 & 1.11 & 21.38 & 4.28 & 23.4 & 2.70 & 19,98 & 6.61 & 23.9 & 3.24 \\
\hline Sep & 7.58 & 1.13 & 20.2 & 0.89 & 17.09 & 4.14 & 20.4 & 2.09 & 9.32 & 5.32 & 21.3 & 2.01 \\
\hline Oct & 4.88 & 1.16 & 15.7 & 0.61 & 10.37 & 4.34 & 16.0 & 1.51 & 7.68 & 8.95 & 16.7 & 2.25 \\
\hline Nov & 3.91 & 1.89 & 13.9 & 0.62 & 10.92 & 6.11 & 13.9 & 1.59 & 8.22 & 9.73 & 14.2 & 2.04 \\
\hline Dec & 8.24 & 6.03 & 14.0 & 1.53 & 10.11 & 7.50 & 12.8 & 1.70 & 6.95 & 13.05 & 13.9 & 2.49 \\
\hline Annual production & & & & 13.30 & & & & 27.33 & & & & 26.38 \\
\hline Mean $P / \bar{B}$ ratio & & & & 1.25 & & & & 1.08 & & & & 1.37 \\
\hline DW production & & & & 50.73 & & & & 122.00 & & & & 75.64 \\
\hline
\end{tabular}

at Site B (Table 8), and the corresponding DW production from $50.73 \mathrm{~g} \mathrm{~m}^{-2} \mathrm{yr}^{-1}$ (Site A) to $122.0 \mathrm{~g} \mathrm{~m}^{-2} \mathrm{yr}^{-1}$ (Site $B)$. The production/biomass $(P / \bar{B})$ ratio was highest (1.37) at Site $C$, where biomass of juveniles made a relatively greater contribution to the total biomass (Table 8). In order to obtain an annual estimate of benthic macroinvertebrate production over the whole main water body, we estimated in the field the proportion of the total surface area of the lagoon system that could be represented (hydrodynamic regime, depth, silt content, algal cover species) by Sites $A, B$ and $C$ (Site A, 53\%; Site B, 9\%; Site C, 38\%). Each of the 3 estimates of mean annual production (Table 8 ) was then weighted by the corresponding contribution to the surface area, and a total production of 19.5 (66.6) $\mathrm{g}$ AFDW (DW) $\mathrm{m}^{-2} \mathrm{yr}^{-1}$ estimated by addition.

\section{DISCUSSION}

\section{Macroinvertebrate community composition and its spatial and temporal distribution}

The species composition of macroinvertebrate fauna in the ecosystem studied (with species typical of coastal lagoons such as Hydrobia minoricensis, $H$. ventrosa, Cerastoderma glaucum, Lakanesphaera hookeri and Nereis diversicolor (Barnes 1980), a small total number of species, strong dominance in number and abundance by a few of these species, and low diversity) is very similar to the situation previously found in other lagoon systems along the Mediterranean and Atlantic coasts of Europe /Guelorget \& Michel 1979,
Labourg 1979, Ardizzone 1984, Gamito 1989). The large fluctuations in environmental conditions ensure that only species tolerant to changes in temperature and salinity can become adapted to this kind of coastal ecosystem. However, neither water temperature, salinity nor sediment characteristics seem to be the main factors determining the distribution of these tolerant species within the study area. The only exception was the negative correlation observed between the density of Chironomus salinarius and the salinity in the main water body, and its positive correlation with the sedimentary silt content in all the studied areas. Guelorget et al. (1983) studied the horizontal biological zonation of Mediterranean coastal lagoons and observed a similar distribution of benthic species from the mouth of the lagoon (sea water) to either hyposaline or hypersaline environments. They proposed the theory of confinement as a model to explain the horizontal zonation of benthic assemblages in coastal lagoons. This theory rejects the salinity as the main parameter in governing biological gradients and proposes the confinement, which represents the turnover time of marine water, as the main parameter. The species composition and distribution observed in our study seem to respond somewhat to this theory. Thus, at Sites $A, B$ and $C$, in the main water body, with low rates of water renewal and high water salinity during most the year, the species composition was similar to that previously found in both brackish (Guelorget \& Michel 1979, Labourg 1979, Reymond 1991) and hypersaline (Mason 1986, Britton \& Johnson 1987) coastal lagoons. In these aquatic systems, a low marine water exchange can cause hyposalinity or hypersalinity depending on the 
presence or absence of freshwater inputs respectively. A slightly increasing gradient of confinement exists from Sites A and B to Site C, with the latter showing a higher density of species that would be dominant in stagnant (hyposaline and hypersaline) systems, e.g. chironomid larvae and beetles. At Site D, situated in a pond with a high rate of sea water renewal, the amphipod Corophium acherusicum and the cumacean Iphinoe trispinosa appear. These are abundant species in tidal channels outside the study area (pers, obs.). Furthermore, the correlation observed between C. salinarius density and the silt content in the sediment could be explained as a consequence of the water dynamics at the different sampling sites rather than as a selection by the species of this sediment characteristic: the reduced and calm water circulation at Site $C$ must cause both a higher degree of confinement and a higher silt content in the sediment. More recently, Pérez-Ruzafa \& Marcos (1993) proposed that the confinement concept must be interpreted with regard to the capability of the species to colonize these environments from the point of view of interspecific competition. We speculate that the species which dominated these environments would be tolerant species but less competitive than marine species. So they would be the most abundant only in sufficiently confined areas, where the environmental conditions would avoid high reproductive and inmigration rates of marine species. But, field manipulative experiments must be carried out before concluding if the confinement is or is not the main factor structuring the macrobenthic community of shallow coastal lagoons.

The biomass of algal cover has been recorded as an important factor in determining the density of benthic fauna in shallow marine and estuarine ecosystems. On the whole, the abundance of macrofauna is higher in zones with vegetative cover than in bare zones (Lewis 1984, Summerson \& Peterson 1984, Castel et al. 1989, Edgar 1990b). Nevertheless, some species seem to be adversely affected by algal cover (Kalejta \& Hockey 1991). Of the 6 most abundant species in this study, epifaunal species were positively affected by the presence of macroalgae, while infaunal species were not affected (Capitella capitata) or negatively affected (Nereis diversicolor). Effects of the presence of algal cover on the macroinvertebrate community have been attributed to modification of biotic interactions, such as predation and availability of food or living space (Heck \& Thoman 1981, Lewis 1984, Summerson \& Peterson 1984, Stoner 1985, Schneider \& Mann 1991), and modification of physico-chemical sediment characteristics (Kalejta \& Hockey 1991). In the ecosystem studied, the lagoon area used for extensive aquaculture supported large populations of predators (reared fish species and shorebirds). This could explain the higher densities of some macroinvertebrate species in samples containing macroalgae as a result of the protection from predation offered by these algae. At the same time, the presence of an algal layer could adversely influence the infauna by shading and by creating anoxic conditions immediately below the algae (Sundbäck et al. 1990). Furthermore, the capacity to detect shadows, that leads in $N$. diversicolor to a retreat of the animal into its burrow, and has been interpreted as a possible way to avoid predators (Lambert et al. 1992), must be more efficient in bare areas and could explain the negative relationship between the density of this species and macroalgal biomass. In the pond used to rear seabream (Site D), where fish are stocked at a high density of $3 \mathrm{~kg} \mathrm{~m}^{-2}$ and the hydrodynamic regime prevent macroalgae from proliferating, both the high density of predators and the lack of an algal refuge reduce macroinvertebrate density.

Seasonal patterns of macroinvertebrate abundance in temperate marine soft-bottom habitats have frequently been found, with a peak of abundance in winter-spring (Guelorget \& Michel 1979, Castel et al. 1989. Service \& Feller 1992) and sometimes a second peak in autumn (Subrahmanyam \& Coultas 1980, Kalejta \& Hockey 1991) at low latitudes of the temperate areas. In the present study the winter density peak was followed by a reduction in spring at Sites $A$ and C. Furthermore, a comparison of the seasonal density patterns previously found in similar ecosystems for species such as Chironomus salinarius (Guelorget \& Michel 1979). Microdeutopus gryllotalpa (Anger 1979, Taramelli \& Pezzali 1986, Karakiri \& Nicolaidou 1987), Nereis diversicolor and Capitella capitata (Guelorget \& Michel 1979, Martín 1991) with those here indicates the main difference is again the early spring reduction in abundance. During spring, when the gates of the San Francisco de Asís system remained open, Sites A and $C$ were flooded only during high water of spring tides. The resulting prolonged emersion could lead to an increase of predatory pressure by birds (Pérez-Hurtado 1992), of faunal death by desiccation (Hummel et al. 1988) and/or of migratory movements to the deeper submerged channels; Site B, situated in one of these channels, showed in April a high macrofaunal density. In late summer there was a further decrease in macrofaunal density, coinciding with a period of high water temperature and salinity, and of low oxygen concentration (Arias \& Drake 1987). These environmental conditions, as has been suggested by Service \& Feller (1992), could force macrobenthic infauna to spend more time in the oxygenated upper layer of the sediment, thus making them more vulnerable to predation. Furthermore, warm temperatures increase the feeding activity of predators (Arias 1980, Arias \& Drake 1986), and it has been shown that epibenthic predators may 
be capable of reducing significantly the abundance of benthic macrofauna and meiofauna in the field (Service et al. 1992). Thus, while farther north the maximum densities are usually during the annual warm period which coincides with an increase in reproductive activity (Zajac \& Whitlatch 1982a), in the studied area, where nearly continuous recruitment exists throughout the year, macrofaunal abundance peaks are shifted to winter-early spring. The warmest period, when macrofauna is under more extreme physicochemical conditions and predation pressure, seems to be more critical in the studied system.

Species richness of invertebrates and $H^{\prime}$ and $J^{\prime}$ indices showed low values that are comparable to those reported from other lagoon systems (Amanieu et al. 1977, Labourg 1979, Bachelet et al. 1980). At Sites A and $B$, both number of species and evenness contributed to the seasonal cycle of $H^{\prime}$ and the higher values observed in late autumn-winter reflected a more heterogeneous community (Bachelet et al. 1980). At Site $C$, however, where the number of species remained relatively constant during the year, the seasonal variation of $H^{\prime}$ reflects the seasonally high numerical abundance of certain individual species. The stress caused at Sites $A$ and $C$ during the period when the gates were open is also reflected by a reduction in $H^{\prime}$. At this time, only the most emersionresistant species, such as hydrobiids and Nereis diversicolor (Hummel et al, 1988), were abundant.

The similarity analysis of the samples also showed the overlapping influence of seasonality and hydrodynamic regime. Samples from the seabream culture pond (Site D), which was always submerged and had high renewal rates, were separated from samples of the main water body (Fig. 5). In the last area, with lower rates of sea water renewal and some zones temporarily drained (Site A and C), samples from summer to winter showed higher intersample homogeneity than during the rest of the year. In the first period, the main water body remained relatively isolated or had just been connected with the tidal channel. A comparison of the samples from the lower (Site $C$; cluster Z) and the higher (Sites $A$ and $B$; cluster $W$ ) renewed zones indicates that the interseason/intrazone samples had higher similarity than the intraseason/interzone samples. However, within the area closer to gates (Sites A and B) the intraseason/intersite samples seerned to be more similar than the interseason/intrasite samples. In contrast, in spring and early summer, when the gates were open or had just been closed, some clusters separated by the classification analysis ( $V$ and $\mathrm{X}$ ) contained samples from both the more and less renewed zones. Cluster $V$ and $X$ grouped samples with high and low density of Microdeutopus gryllotalpa respectively. There appeared to be a time lag between the enclosure/opening of the main water body and the presence/lack of differences in the macrobenthic community between the different zones. This time lag could have contributed to the non-significant correlation between the abundance of the most abundant macroinvertebrate species and the level of water in the main water body.

\section{Macroinvertebrate production}

Kalejta \& Hockey (1991) found that production of macrofaunal invertebrates in estuaries and coastal lagoons at temperate and subtropical latitudes was positively correlated with mean annual water temperature and negatively correlated with latitude. According to their results, the expected production of the ecosystem we studied would have values of about 53 and $73 \mathrm{~g} \mathrm{~m}^{-2} \mathrm{yr}^{-1}$ (DW), as a function of the latitude and mean water temperature respectively. These values are very close to the estimates of production at Sites $\mathrm{A}$ and $\mathrm{C}$, but somewhat lower than estimates at Site $\mathrm{B}$. When considering the whole main water body, the estimate of production $\left(66.6 \mathrm{~g} \mathrm{~m}^{-2} \mathrm{yr}^{-1}\right)$ is close to the expected production from Kalejta \& Hockey (1991). However, $P / \bar{B}$ ratios estimated in our study, although similar to ratios recorded in some estuarine areas at higher latitudes (Warwick \& Price 1975, Wolff \& de Wolf 1977), were lower than ratios recorded in estuaries and lagoons at latitudes similar to those of the Bay of Cádiz (Puttick 1977, Kalejta \& Hockey 1991). In these coastal ecosystems, previous estimates of $P / \bar{B}$ ratios for the macrobenthic community were variable, depending on factors such as the age structure of populations and taxonomic group composition. On the whole, higher $P / \bar{B}$ values were obtained for populations dominated by younger individuals (Möller 1985), and for non-molluscan groups such as polychaetes and amphipods, while intermediate and low values were found for hydrobiid and bivalve species respectively (Chambers \& Milne 1975, Warwick \& Price 1975, Wolff \& de Wolf 1977, Bachelet et al. 1980, Siegismund 1982, Möller 1985). In the community studied, the biomass was dominated by adult gastropods and bivalves, and this could explain the relatively low values of the $P / \bar{B}$ ratio. Nevertheless, the production of chironomid larvae, which is a larval group not included by Edgar (1990a) in the calculation of equations used in the present study, has been underestimated (Drake \& Arias 1994). Furthermore, we used a $0.3 \mathrm{~mm}$ mesh in order to retain the young individuals of the benthic macroinvertebrates. The production attributable to young individuals was negligible for some species, e.g. Chironomus spp. (Graham \& Burns 1983), but very important for others, e.g. 
Hydrobia spp. (Bachelet \& Yacine-Kassab 1987). This being the case, the expected $P / \bar{B}$ ratios would be even higher than those recorded in the previously cited literature. Therefore the accuracy of our first estimate of macroinvertebrate production in this ecosystem should be tested by calculating the production of the most abundant species by the classical cohort summation of losses method (Crisp 1971) or by the sizefrequency method (Benke 1979), and a correction factor could then be incorporated into the more easily calculated equations of Edgar (1990a).

\section{The benthic macroinvertebrate community and human management of the ecosystem}

The human use of the saltmarsh area, where the studied lagoon system is located, has converted this intertidal environment to semi-enclosed lagoon systems and, thus, benthic macrofauna that was found in the studied main water body was typical of coastal lagoons. During most of the year, while reared fish species were growing, this water body remained continuously flooded, but with a low rate of water renewal. At this time a somewhat horizontal biological zonation of the macrobenthic community was observed. However, when the abundance of larvae of fish species suitable for extensive rearing peaked in the external tidal channels (Drake \& Arias 1991), the gates of the main water body were opened (12 February to 15 April) to permit the entrance of fish larvae. This converted, temporarily, the $\sim 90 \%$ of main water body to an intertidal zone. In addition, a substantial proportion of pelagic macrofaunal larvae, which probably were present in the water column at this time, could have been removed from the lagoon. A decrease of the benthic macroinvertebrate number of species and density was observed at the emerged areas (Sites A and $C$ ), and the interzone differences, previously observed, were not evident. On the other hand, since the temporal timing of a disturbance seems to influence the posterior faunal succession (Zajac \& Whitlatch 1982b), a change in the timing of the gate opening, connected to aquaculture practices, could result in a different benthic community structure to that recorded in this study. Furthermore, the use of a part of the studied system for semi-intensive aquaculture, and the consequent increase of the rate of water renewal (by pumping), could have contributed to the appearance in the seabream pond (Site C) of species that were abundant in tidal channel outside the studied area. All these facts suggest that the human use of the ecosystem should be considerated as an important factor affecting the macrobenthic community of the studied lagoon.
Acknowledgements. This research was supported financially by Comisión Asesora de Investigación Científica y Técnica (NAT91-1008 Project), Consejo Superior de Investigaciones Científicas and Junta de Andalucía. We thank PEMARES, especially Mr A. Sánchez-LaMadrid and Mr J. L. Muñoz, for helping with the granulometric study, Dr J. N. Tourenq, Dr J. Junoy, Dr J. L. Cervera and Mr S. F. García-Martín for the identification of particular species, Ms M. Espigares for her invaluable assistance, and 3 anonymous reviewers for provid. ing helpful suggestions.

\section{LITERATURE CITED}

Amanieu, M. (1967). Introduction à l'étude écologique des réservoirs à poissons de la région d'Arcachon. Vie Milieu 18(B): 381-442

Amanieu, M. (1973). Ecologie et exploitation des étangs et lagunes saumâtres du littoral français. Annls Soc. r. zool. Belg. 103: 79-94

Amanieu, M., Guelorget, O., Michel, P. (1977). Richesse et diversité de là macrofaune benthique d'une lagune littorale méditerranée. Vie Milieu 27(B): 85-109

Anger, K. (1979). Untersuchungen zum Lebenszyklus der Amphipoden Bathyporeia sarsi, Microdeutopus gryllotalpa und Corophium insidiosum in der Kieler Bucht. Mitt. Zool. Mus. Univ. Kiel 1: 1-6

Ardizzone, G. D. (1984). Biological characteristics, exploitation and management of fishery resources in coastal lakes of central Italy. Etud. Rev. 61: 461-476

Arias, A. M. (1980). Crecimiento, régimen alimentario y reproducción de la dorada (Sparus auratus L.) y del robalo (Dicentrarchus labrax L.) en los esteros de Cádiz. Invest. pesq. 44: $59-83$

Arias, A. M., Drake, P. (1985). Estructura de la población y régimen alimentario de Anguilla anguilla en los esteros de San Fernando (Cádiz). Invest. pesq. 49: 475-491

Arias, A. M. Drake, P. (1986). Contribución al conocimiento de la biología de Valencia hispanica Val., 1846 (Pisces, Ciprinodontidae) en el SO ibérico. Invest. pesq. 50: 23-36

Arias, A. M., Drake, P. (1987). Evolución de las condiciones fisicoquímicas y biológicas de un estero y su relación con los ciclos de estancamiento y renovación del agua. Invest. pesq. 51: 79-95

Arias, A. M., Drake, P. (1990). Captación de alevines con las mareas en los esteros de la bahía de Cádiz. Inf. Téc. Invest. pesq. 156: 3-33

Arias, A. M., Rodríguez, A. (1977). Physico-chemical factors and faunistic composition in the saltmarshes of Cádiz (Southern Spain). Comm. Meet. int. Coun. Explor. Sea CM-ICES/K:6: Shellfish and benthos, 1-8

Bachelet, G., Bouchet, J. M., Lissalde, J. P. (1980). Les peuplements benthiques dans l'estuaire de la Gironde: biomasse, productivité et évolution structurale. Oceanis 6: 593-620

Bachelet, G., Yacine-Kassab, M. (1987). Intégration de la phase post-recrutée dans la dynamique des populations du gastéropode intertidal Hydrobia ulvae (Pennat). J. exp. mar. Biol. Ecol. 111: 37-60

Barnes, R. S. K. (1980). Coastal lagoons. The natural history of a neglected habitat. Cambridge University Press, Cambridge

Benke, A. C. (1979). A modification of the Hynes method for estimating secondary production with particular significance for multivoltine populations. Limnol. Oceanogr. 34 : $168-171$

Britton, R. H., Johnson, A. R. (1987). An ecological account of a Mediterranean salina: the Salin de Giraud, Camargue 
(S. France). Biol. Conserv. 42: 185-230

Castel, J., Labourg, J. P., Escaravage, V., Auby, I., García, M. E. (1989). Influence of seagrass beds and oyster parks on the abundance and biomass patterns of meio- and macrobenthos in tidal flats. Estuar. coast. Shelf Sci. 28: 71-85

Chambers, M. R., Milne, H. (1975). Life cycle and production of Nereis diversicolor O.F. Müller in the Ythan Estuary, Scotland. Estuar. coast. mar. Sci. 3: 1.33-144

Chassany-de Casabianca. M. L. (1980). Evolution biocénotique du bord des étangs en Corse. Tethys 9: 299-308

Clément, O. (1986). L'aquaculture dans les marais: l'exemple des marais saumâtres endigués de la côte atlantique. In: Barnabé, G. (ed.) Aquaculture. Technique et Documentation (Lavoisier), Paris, p. 773-791

Craft, C. B., Seneca, E. D. Broome, S. W. (1991). Loss on ignition and Kjeldahl digestion for estimating organic carbon and total nitrogen in estuarine marsh soils: calibration with dry combustion. Estuaries 14: 175-179

Crisp, D. J. (1971). Energy flow measurements. In: Holme, N. A., McIntyre, A. D. (eds.) Methods for the study of marine benthos. Blackwell, Oxford

Drake, P., Arias, A. M. (1991). Composition and seasonal fluctuations of the ichthyoplankton community in a shallow tidal channel of Cádiz Bay. J. Fish Biol. 39: 245-263

Drake, P., Arias, A. M. (1994). Distribution and production of Chironomus salinarius (Diptera: Chironomidae) in a shallow coastal lagoon in the Bay of Cádiz). Hydrobiologia (in press)

Drake, P., Arias, A. M., Gállego, L. (1984). Biología de los Mugilidos en los esteros de las salinas de San Fernando. III. Hábitos alimentarios y su relación con la morfometría del aparato digestivo. Investigación pesq. 48: 225-255

Edgar, G. J. (1990a). The use of the size structure of benthic macrofaunal communities to estimate faunal biomass and secondary production. J. exp. mar. Biol. Ecol. 137: 195-214

Edgar, G. J. (1990b). The influence of plant structure on the species richness, biomass and secondary production of macrofaunal assemblages associated with Western Australian seagrass beds. J. exp. mar. Biol. Ecol. 137: 215-240

Fiala, M. (1972). Etudes physico-chimiques des eaux et sédiments de I'étang Bages Sigean (Aude). Vie Milieu 23(B): $15-50$

Gamito, S. J. (1987). The benthic macrofauna of some water reservoirs of saltpans from Ria Formosa (Portugal). In: Ros, J. D. (ed.) Topics in marine biology. Scient. mar 53: $639-644$

Gee, G. W., Bauder, J. W. (1986). Particle size analysis. In: Methods of soil analysis. I. Physical and Mineralogical methods. American Society of Agronomy, Madison, WI

Graham, A. A., Burns, C. W. (1983). Production and ecology of benthic chironomid larvae (Diptera) in Lake Hayes, New Zealand, a warm-monomictic eutrophic lake. Int. Rev. ges. Hydrobiol. 68: 351-377

Guelorget, O., Frisoni, G. F., Perthuisot, P. (1983). La zonation biologique des milieux lagunaires: définition d'une échelle de confinement dans le domaine paralique méditerranéen. J. Rech. Océanogr. 3: 15-35

Guelorget, O., Michel, P. (1979). Les peuplements benthiques d'un étang littoral languedocien, l'étang du Prevost (Hérault). 1. Étude quantitative de la macrofaune des vases. Tethys 9: 49-64

Heck, K. L.. Thoman, T A. (1981). Experiments on predatorprey interactions in vegetated aquatic habitats. J. exp mar. Biol. Ecol. 53: 125-134

Heck, K. L., van Belle, G., Simberloff, D. (1975). Explicit calculation of the rarefaction diversity measurement and the determination of sufficient sample size. Ecology 56 $1459-1461$

Hummel, H., Fotuin, A. W., De Wolf, L., Meijboom, A. (1988) Mortality of intertidal benthic animals after a period of prolonged emersion. J. exp, mar. Biol. Ecol. 121: 247-254

Kalejta, B., Hockey, P. A. R. (1991). Distribution, abundance and productivity of benthic invertebrates at the Berg River estuary, South Africa. Estuar. coast. Shelf Sci. 33: 175-191

Karakiri, M. Nicolaidou, A. (1987). Population studies on the Amphipoda of Mazoma Lagoon (Greece). Helgoländer Meeresuntersuch, 41: 453-464

Labourg, P. J. (1976). Les réservoirs à poissons du bassin d'Arcachon et l'élevage extensif de poissons euryhalins (muges, anguilles, bars, daurades). Bull. Stn biol. Arcachon 28: $1-19$

Labourg, P. J. (1979). Structure et évolution de la macrofaune invertebrée d'un écosystème lagunaire aménagé (réservoirs à poissons de Certes). Publ. Centre Nat. Exploitation Océans (CNEXO). Actes Colloq. 7: 591-614

Lambert, R., Desrosiers, G., Retière, C., Miron, G. (1992). Activité de prospection de son aire d'alimentation par la polychète Nereis diversicolor (O.F. Múller): données préliminaires. Cah. Biol. Mar. 33: 43-54

Lewis, F. G. (1984). Distribution of macrobenthic crustaceans associated with Thalassia, Hadule and bare sand substrata. Mar. Ecol. Prog. Ser. 19: 101-113

Ludwig, J. A., Reynolds, J. F. (1988) Statistical ecology: a primer on methods and computing. Wiley Interscience, New York

Martín, D. (1991). Macroinfauna de una bahía Mediterránea Estudio de los niveles de organización de las poblaciones de Anélidos Poliquetos. Ph.D. thesis, University of Barcelona

Mason, C. F. (1986). Invertebrate population and biomass over four years in a coastal, saline lagoon. Hydrobiologia 133: $21-29$.

Möller, P. (1985). Production and abundance of juvenile Nereis diversicolor, and oogenic cycle of adults in shallow waters of western Sweden. J. mar. biol. Ass. U.K. 65: $603-616$

Pérez-Hurtado, A. (1992). Ecología alimentaria de las aves limícolas invernantes en la Bahía de Cádiz (orden Charadriiformes). Distribución y uso del habitat. Ph.D. thesis, University of Sevilla

Pérez-Ruzafa, A., Marcos, C. (1993). La teoría del confinamiento como modelo para explicar la estructura y zonación horizontal de las comunidades bentónicas en las lagunas costeras. Publ. Espec. Inst. Esp. Oceanogr. 11. $347-358$

Pielou, E. C. (1966). The measurement of diversity in different types of biological collections. J theor. Biol. 13: 131-144

Puttick, G. M. (1977). Spatial and temporal variations in intertidal animal distribution at Langebaan Lagoon. South Africa. Trans. Roy. Soc. S. Afr. 42: 403-440

Quignard, J. P. (1984). Les caractéristiques biologiques et environnementales des lagunes en tant que base biologique de l'aménagement des pêcheries. Etud. Rev. 61: $3-38$

Ravagnan, G. (1978). Vallicoltura moderna. Ed. Edagricole, Bologna

Reymond, H. (1991). Dynamique de la chaine hétérorotrophe benthique des marais maritimes en période estivale et son impact sur les production aquacoles de carnivores: Penaeus japonicus, un modèle d'étude. Ph.D., Univ. of Paris

Sacchi, C. F., Porchedou, A., Sconfietti, R. (1988). Recherches bionomiques expérimentales dans l'étang de is Benas 
(Prov. Oristano, Saratalgue). Rapp. p.-v. Réun. Comm. int. Explor. Scient. Mer Méditerr. 31: 66

Schneider, F. I., Mann, K. H. (1991). Species specific relationships of invertebrates to vegetation in a seagrass bed. I. Correlational studies. J. exp. mar. Biol. Ecol. 145: 101-117

Service, S. K., Feller, R. J. (1992). Long-term trends of subtidal macrobenthos in North Inlet, South Carolina. Hydrobiologia 231: $13-40$

Service, S. K., Feller, R. J., Coull, B. C., Woods, R. (1992). Predation effect of three fish species and shrimp on macrobenthos and meiobenthos in microcosms. Estuar. coast. Shelf Sci. 34: 277-293

Siegismund, H. R. (1982). Life cycle and production of Hydrobia ventrosa and $H$. neglecta (Mollusca: Prosobranchia). Mar. Ecol. Prog. Ser. 7: 75-82

Stoner, A. W. (1985). Penicillus capitatus: an algal island for macrocrustaceans. Mar. Ecol. Prog. Ser. 26: 279-287

Subrahmanyam, C. B., Coultas, C. L. (1980). Studies on the animal communities in two North Florida salt marshes. III. Seasonal fluctuations of fish and macroinvertebrates. Bull. mar. Sci. 30: 790-818

This article was submitted to the editor
Summerson, H. C., Peterson, C. H. (1984). Role of predation in organizing benthic communities of temperate-zone seagrass bed. Mar. Ecol. Prog. Ser. 15: 63-77

Sundbäck, K, Jönsson, B., Nilson, P., Lindström, I. (1990). Impact of accumulating drifting macroalgae on a shallowwater sediment system: an experimental study. Mar. Ecol. Prog. Ser. 58: 261-274

Taramelli, E., Pezzali, S. (1986). Ecologia e distribuzione dei crostacei anfipodi nei laghi costieri della provincia di Latina. Boll. Mus. civ. Stor. nat. Verona 13: 295-318

Warwick, R. M., Price, R. (1975), Macrofauna production in an estuarine mud-flat. J. mar. biol. Ass. U.K. 55: 1-18

Wolff, W. J., de Wolf, L. (1977). Biomass and production of zoobenthos in the Grevelingen Estuary, The Netherlands. Estuar. coast. mar. Sci. 5: 1--24

Zajac, R. N., Whitlatch, R. B. (1982a). Responses of estuarine infauna to disturbance. I. Spatial and temporal variation of initial recolonization. Mar. Ecol. Prog. Ser. 10: 1-14

Zajac, R. N., Whitlatch, R. B. (1982b). Responses of estuarine infauna to disturbance. II. Spatial and temporal variation of succession. Mar. Ecol. Prog. Ser. 10: 15-27

Manuscript first received: June 14, 1993

Revised version accepted: September 6, 1994 